Portland State University

PDXScholar

$1-1-2012$

\title{
The Tea Party and Occupy Movements: Populism and Protest
}

Stephanie Stanley

Portland State University

Follow this and additional works at: https://pdxscholar.library.pdx.edu/honorstheses Let us know how access to this document benefits you.

\section{Recommended Citation}

Stanley, Stephanie, "The Tea Party and Occupy Movements: Populism and Protest" (2012). University Honors Theses. Paper 2.

https://doi.org/10.15760/honors.2

This Thesis is brought to you for free and open access. It has been accepted for inclusion in University Honors Theses by an authorized administrator of PDXScholar. Please contact us if we can make this document more accessible: pdxscholar@pdx.edu. 
Stephanie Stanley

Portland State University

\section{The Tea Party and Occupy Movements: Populism and Protest}

\section{Introduction}

The rise of the Tea Party and the Occupy Wall Street movements has led to numerous debates on the true affect that these movements have on American politics, where they came from, what their future looks like, and what kind of movements the Tea Party and Occupy Wall Street movements are. I will provide perspective on these debates by using a framework that has not yet been applied to a comparison of the Tea Party and the Occupy Wall Street movements. First, I will examine both of these movements through a political lens to determine the most appropriate classification for each of these movements. Then I will view both the Tea Party and Occupy Wall Street movements through an historical lens in order to demonstrate how previous American movements have influenced these two contemporary movements.

The specific political lens I will use is populism because this theory seems to be the most accurate in explaining the Tea Party and Occupy Wall Street movements. Some work has already been done with the Tea Party and populism, which also justifies the use of this framework. Both of these movements are driven by independent groups of citizens who are anti-government, anti-political party, and antiestablishment, and have a set of demands for the ruling class; these are characteristics 
of populism. Simply labeling these movements as populist, however, is more problematic than identifying the aforementioned dimensions of each movement. The nature of populism, which is defined by decentralized movements that are highly fluid because they mold significantly to their environment, introduces a unique set of problems and nuances that require attention.

In order to discuss properly the Tea Party and Occupy Wall Street movements in relation to populism, I will split my study of populism into two chapters. The first chapter simply answers the question "What is populism?" and explains why both the Tea Party and Occupy Wall Street movements qualify as populist movements. In this chapter, I will explain the problems with regard to the theory of populism. One problem is that because populist movements vary depending on the context in which they arise, having one all-encompassing theory produces either an overly vague or overly specific theory. Therefore, to answer the question "What is populism?" in this first chapter, I will generate a broad profile of populism based on the agreed upon aspects of all populist movements. I will discuss what populism looks like specifically within a democracy, the context in which both of the movements of interest occur.

In the second chapter, I will build upon the basic profile of populism from chapter one and explain the seven types of populism. The scholarly response to dealing with the problem of creating one, all-encompassing theory of populism was to create types of populism beyond just the basic dimensions of populism. These distinct types of populism are useful because, when paired with the general profile of populism, they provide a view of the important features of different types of populism 
without making universal statements that accidently remove true populist movements like a more specific, universal definition would. For each of these seven types of populism, I will provide case studies that will further clarify the types. To conclude this chapter, I will classify the Tea Party and Occupy Wall Street movements into the most appropriate type of populism.

Finally, in the third chapter, I will explain the Tea Party and Occupy Wall Street movements within a historical narrative, which will clarify both of these movements even more. American politics has a substantial history of populism, and each new movement builds on different specific aspects of some of the previous American populist movements. Therefore, I will construct a brief historical narrative of American populist movements, explain why the two movements should be considered populist, and which type or types of populism they represent the best. I will conclude the chapter on historical narrative with the Tea Party and Occupy Wall Street movements. I will demonstrate how both of these movements have drawn upon previous movements and then assess the potential future of both movements based on their historical counterparts.

Although there has been some limited scholarship done on the Tea Party and the first bits of research on Occupy Wall Street are beginning to emerge, very little if any has been done to treat both movements together. This paper will not only discuss both movements simultaneously as contemporary movements, but I will also add the aforementioned framework that includes both a political lens and a historical lens, which, to my knowledge, is a unique approach. Thus far the main historical comparisons for the Tea Party has, of course, been the Sons of Liberty's Boston Tea 
Party and for Occupy Wall Street, the student protests of the 1960s and 1970s, William Jennings Bryan's presidential run in 1986, and the WTO protest of 1999 in Seattle. While these are fair comparisons, there are more parallels to these two movements that should also be explored. 


\section{Chapter 1: What is Populism?}

Populism is a tricky concept to describe because there are multiple contexts in which "populism" has been identified. Scholars who study populism tend to agree with Sir Isaiah Berlin's diagnosis that populism has a "Cinderella complex." The "Cinderella complex" is that there is a shoe, which is the word "populism" and there is a foot, which is what populism really is, and there are many feet that almost fit in the shoe of “populism," but a perfect fit- Cinderella's foot- has not yet been identified (Canovan, Populism, 7; Taggart, 2). The overall consensus is that when scholars try to establish an all-encompassing definition of populism, it is either too vague or too narrow. (Canovan, Two Strategies; Lutz). This is largely due to the fact that scholars have not studied populism very extensively, and when it has been studied, it has mainly been studied in a comparative context, which limits its universality. Furthermore, there are numerous case studies of populism from around the world, but these case studies have yet to be synthesized in a coherent manner. Canovan's approach is to categorize populism into seven distinct types of populism, which Taggart suggests has resulted in populism becoming a "fractured concept" (Taggart, 22).

Taggart also observes that populism has a unique chameleon quality because its environment plays a significant role in crafting it (Taggart, 2). This is what led to the seven specific types of populism, which I will explain in depth in the second chapter of this paper. Because populist movements are significantly shaped by their political contexts and have occurred in numerous countries, regions, and historical periods, it is not surprising that one broad definition of populism cannot offer a comprehensive account of every kind of populism. This does not mean that the vague definition and 
general characteristics of populism (Figure 1) does not provide a useful framework for studying populism. On the contrary, it explains why seemingly unlinked movements are classified together and lays a foundation for a more in depth discussion of the different types of populism.

Figure 1: Characteristics of Populism

\begin{tabular}{|c|c|c|}
\hline Characteristic & Definition & Example \\
\hline People vs. Elite & $\begin{array}{l}\text { People: common, ordinary folk; elite: opposition } \\
\text { group, the political/economic power }\end{array}$ & $\begin{array}{l}\text { People: farmers } \\
\text { Elites: corporations, gov't }\end{array}$ \\
\hline The Demand & $\begin{array}{l}\text { Set of unmet desires of the people that the status quo } \\
\text { has failed to meet }\end{array}$ & $\begin{array}{l}\text { Boston Tea Party: no taxation } \\
\text { without representation }\end{array}$ \\
\hline The Crisis & Problem that sparks the populist movement & Economic Crisis of ' 08 \\
\hline The Trajectory & $\begin{array}{l}\text { Top-down (politicians/ intellectuals to people) or } \\
\text { Bottom up (grassroots to national) }\end{array}$ & $\begin{array}{l}\text { Farmers' Alliance formed } \\
\text { People's Party (bottom-up) }\end{array}$ \\
\hline Affect on Public Debate & $\begin{array}{l}\text { 1. Simplicity 2. Sovereignty of the People } \\
\text { 3. Creates Dichotomy }\end{array}$ & $\begin{array}{l}\text { "We are the } 99 \% \text { vs. the } 1 \% " \\
\text { (simple, dichotomous) }\end{array}$ \\
\hline
\end{tabular}

The first common characteristic of populist movements is how the people within the movement see themselves and how they see their opposition. Populists see themselves as either a part of "the people" or, at the very least, believe they are acting on behalf of "the people." On the other hand, the opposition is labeled as "the elites" and are seen as the oppressors who fail to meet the demands of "the people." The interesting thing about "the people" and "the elites" is that these two groups are not static; they are comprised of whichever political group is relevant to that specific populist movement. Nonetheless, "the people" represent the group of the governed, which holds less political or economic power than "the elites" (Taggart, 2; Canovan, 286; Meny \& Surel, 101-109). 
The general assumptions in populist movements in relation to these two actors are twofold. First, the wisdom of "the people" or the "ordinary man" is not only sufficient to make political decisions, but it is the most appropriate mechanism to make political decisions (Mayer; Canovan, 233; Kazin, 19). Secondly, "the elites" have either violated the rights of "the people" or they have failed to satisfy a demand or set of demands given to them by "the people." These reasons are why "the elites" are the opposing element to "the people" (Meny and Surel, 11-12). Mayer, et al. take this a step further in explaining a specific type of populism called identity populism, in which "the people" do not simply feel that their demands are unmet. Instead, they believe the violation goes beyond unmet demands and becomes a problem of identity. According to "the people," "the elites" have violated the very cultural identity of various groups of "the people" (Mayer). Even with this twist on the basic parameters of populism, "the elites" are still the opposing force against "the people."

The conflict between "the elites" and "the people" is more than just a general power struggle. "The people" genuinely feel betrayed by the "the elites," the government, and the institutions, resulting in a general loss of trust between the ruling class and the ruled (Meny and Surel, 11). They interpret the lack of the people's voice being heard as a systemic problem with the institutions and their procedures as a whole (Taggart, 93). This is key in democratic populism because the system claims to rely on the consent of the governed, which I will discuss in depth later in this chapter. In all cases of populism, however, the rejection of public demands is the catalyst to any populist uprising. In this way, populism is always a reactionary phenomenon (Canovan, 220; Taggart, 2). 
The criticism of the construct of "the people" is twofold. First, the concept does not always envelop the entirety of the masses or the ruled. In some cases, "the people" can be limited to workers in unions or peasant farmers. Secondly, "the people" can be more defined by what they are not than what they are, which presents the problem of actually defining "the people" (Meny and Surel, 31, 101). However, "the people" is not an entirely negative concept. A universal aspect of "the people" within any given populist movement is their idealization of the people and the heartland. The heartland is an imagined space or territory that encompasses not only the people but also the values and beliefs of the people, which are deemed to be worth defending. Within the heartland, "the people" become a homogenous group, regardless of the diverse subgroups that make up "the people." (Taggart, 95-96).

Scholars frame this disconnect between "the people" and "the elites" as a broken link between the silent majority and their representatives. This link is broken by a corrupted political system corrupting politicians and the instances in which "special interests" are seen to have taken over the political process. This broken link in democratic contexts is seen as a breakdown of the representativeness of the representative system. This can be fixed by a linkage that increases citizen participation in policy decisions, a foundational demand of populist movements. That specific type of linkage is the plebiscitarianism linkage, which is less episodic than just voting in an election. With this type of linkage ideas are presented to the people, and the people either support or reject them via direct democracy. As I will explain later, direct democracy is a common and important consequence of populism, particularly populism in democracies (Barr). 
The second characteristic of populism in general is an unmet demand or set of demands. This is a result of the elites not responding to the demands of the people, the current institutions and structures not being equipped to respond to such demands, or both (Panizza, 9-12). Meny and Surel identify the sources of dissatisfaction that lead to populist movements to include the following: failure of political parties, failure in policy output, failure of the political class to actually engage and debate the problem, lack of political infrastructure to enact unconventional ideas within the existing systems, failure of political and economic outputs, and a general loss of trust on the part of the people (Meny and Surel, 14). These sources of dissatisfaction lead to the people making an appeal, or set of demands, which contains specific characteristics according to Barr. The appeal is comprised of a combination of an anti-establishment message that requires a personnel change, a call for citizen participation within government, and/or a call for increased accountability of the elites (Barr). The call for increased citizen participation is of particular importance, specifically in democratic populism because it leads to direct democracy, which I will explain in depth in chapter two. The characteristic of a set of demands within populist movements remains constant across all the different types of populism that have been identified.

Another aspect of populism is the anti-institutional, anti-establishment orientation of populist movements that occurs in times of crises. Unlike groups of people such as anarchists, that always have a general anti-establishment orientation, it is important to note that populism arises in times of crisis or perceived crisis according to Taggart (Taggaert, 2, 99). This crisis can materialize as an economic crash or political scandal. The important aspect of the crisis is that it ignites the people to mobilize because they 
see the failure of the status quo to meet their demands. Additionally, populist movements are always short lived, at least as in the form of a populist movement. Because of their inherent ambivalence towards institutions and the fact that they want to correct their problems and corruptions yet feel that those institutions do not fully embody the voice of the people, populist movements are self-limiting. Not only do they have a strong distaste for institutions, they also despise political parties, which are the mechanisms that shape policy outputs within the institutions. Therefore, when they begin to infiltrate and be incorporated into the institutions they hate in order to change them, by definition they cease to be a populist movement. They become part of the actual institution (Taggart, 99, 110).

This explains the tendency for populists to attach themselves to leaders instead of parties, which shortens the life of the movement because leaders have a shorter shelf life than parties do. Populist movements also die out because they have been co-opted by the establishment via politician's populism (Canovan, 51; Taggart, 110). I would also apply Taggart's observation that populism arises during a state of crisis. Since crises are not permanent and do not tend to last long, it would follow that a populist movement would end about the time of the end of the crisis. In fact, many times populist movements become absorbed by political parties and institutions, as I will show with movements such as the People's Party of 1890s in the U.S. This absorption ends the populist aspect of a populist movement as its demands become part of the elites' political agenda.

In fact, populist movements follow two trajectories that result in two conclusions of populist movements, which reiterates this absorption phenomenon. The first trajectory of populist movements is a bottom-up trajectory, which happens when a grassroots 
movement begun and mobilized by the people themselves evolves from a local phenomenon to a more prolific, even national, movement (Canovan, 51). This typically results in politicians and political parties assimilating the populist rhetoric of the movement, and sometimes even enacting the policies put forth by "the people." When this happens, the actual movement itself more or less ceases to exist as a grassroots populist movement. The second trajectory is the inverse, or a top-down phenomenon, in which a movement from the elites becomes grassroots. This happens most notably in dictatorship populism and politician's populism, in which a leader connects with the people, identifies their demands, and leads a crusade to meet those demands (Hackney, 99). That leader either takes on the role of "the outsider," or a person who belongs to the masses and is fighting the system from without, or the role of "the maverick," or a person who is part of the system, but positions himself/herself as sympathetic to the people's appeal, fighting the system from within (Barr).

Even though they do not tend to last long, populist movements have three distinct effects on political debate and discourse. First, they bring simplicity to political debate because of their orientation towards "the people." One characteristic of "the people" is their plain talk that enables the entire body of the people to understand and participate in the political discourse that lies at the heart of every populist movement. Secondly, populism inserts a specific idea of popular sovereignty into the political discourse. Particularly in democracies, populists believe that people are the legitimizing power of the government, and policy must demonstrate a "commitment to 'the people'." Finally, populism dichotomizes the political debate into a strict pro/con debate. There is not 
room for a third or fourth dimension. The dualism that is drawn from the elites vs. the people dichotomy is fundamental to populism itself (Taggart, 112).

The intriguing thing about populism is how it has evolved as a concept over time. Taggart identifies an interesting brand of populism he calls new populism, which will be helpful for me to describe before I discuss the Tea Party and the Occupy Wall Street movements. New populism is predominantly a western form of populism that is a rightwing response to the leftist policies from the 1970s. Like all populist movements, new populism promotes the common sense and the supremacy of the wisdom of the ordinary people. Their specific appeal is that they oppose the welfare state as well as the mixedeconomy capitalist system from the era of the New Deal. They also hold deep resentment towards what they see as the overrepresentation of minorities. New populism is also distinct in its deep mistrust not only of the establishment and institutions, but it also holds a specific animosity for political parties themselves (Taggart, 106-110).

Because I am studying two populist movements within a democracy, it is important to discuss what populism looks like within a democratic context. Democratic governments theoretically operate within a paradox, in that they are supposed to reflect the will of the people and protect the rights of the individual. That tension between the boundaries democracy creates and the idea that democracy should be an expression of the will of the people generates the elitist institutions, which are supposed to be the mechanism to express that will. When those elitist institutions fail to reflect the will of the people or infringe upon the rights of the individual, populism attacks those institutions to restore the supremacy of the people. This paradox is called the doublestrand theory of democracy, and it shows that the very institutionalization of democracy 
begins to set up the conditions for a populist uprising. This is why Canovan describes populism as the shadow of democracy. Because democracies are based on the principle of popular empowerment, they are continually vulnerable to movements that accuse the existing democracy of not responding to popular empowerment and demand a change. (Canovan, Trust the People; Lutz, Review).

Canovan clarifies this relationship between democracy and populism by claiming that an imbalance between the redemptive and pragmatic pieces of democracy leads to populist movements (Canovan, Trust the Peopl; Arditi). The redemptive aspect is that people have the power to save government and society as long as the people participate in the political process. I think it would be appropriate to link this idea with popular sovereignty in that the will of the people is the life blood of democracy. In other words, popular sovereignty "saves" the democratic government from illegitimacy in that it fulfills the very "democratic" ideal of democracy. The pragmatic aspect of democracy is the ability of the government to cope with conflict and public issues through institutions (Canovan, People). However, these institutions do tend to evolve into elitist institutions that become removed from the masses. When there is a sufficient gap between these two parts of democracy, it fosters the rise of a populist movement. The role of this kind of populist movement is akin to a spiritual revival that rejoins the redemptive and pragmatic pieces of democracy. Additionally, these movements tend to attract people to participate in the movement who historically have been non-political people.

David Laycock has identified three elements that define democratic populism. The first element is that the relationship between the people and their representatives undergoes "problematicization." Democracy is supposed to be a manifestation of 
popular sovereignty, but when the people do not believe that democratic institutions are truly representative of their will, people become increasingly disenfranchised with their representatives. This disenfranchisement provides the basis of a populist movement. As Taggart observed, "populism has the task of constructing itself as an entity out of reaction to representative politics." This reaction is typically based on the people perceiving a corruption of their will in both the political and/or economic spheres of government and society. A populist movement in this context can call for the alteration, augmentation, or circumvention of the current institutions, and a common tool they implement is direct democracy. Direct democracy includes recalling people or decisions that are contrary to the people's will and voting on referenda that relies on a vote of the majority to make a measure a law (Laycock, Visions). However, the problem with direct democracy in America, as Canovan points out, is that recalls and referenda can be challenged and reversed within the court system, potentially pushing the populist movements toward more drastic measures (Canovan, Populism, Ch. 5).

The second element is the understanding of equality. Laycock makes a separation of the left-liberal populism with the New Right populism here because of their opposing views of equality. On the left the expression of equality is focused on an egalitarian class system void of "landed and corporate wealth as the basis of political power." The newer liberal ideas espouse that it does not suffice to simply empower the "ordinary people" with voting and civil rights. Instead, the need for equality must also be met with social programs in the form of welfare and other such state-sponsored goods. On the other hand, the New Right, as Laycock describes them, believes that the welfare state is actually the source of inequality. Welfare and other state-sponsored goods and services 
have fostered the emergence of special interest groups that have accumulated sufficient political power to become the new elites (Laycock, Visions). Of course, with populist movements the elites are the problem, and the masses must mobilize against them. To sum up, both right-leaning and left-leaning populist movements blame special interests for eroding the principle of popular sovereignty; they simply identify different actors as the special interests.

Finally, the third element is the conflict between the elites and the people. This element of populism Laycock analyzes is also distinct for the right and left populist movements. Democracy, contrary to its philosophical and theoretical roots, has an exclusionary nature to it as particular segments of the people gain more political and/or economic power than most of the people. The former are then classified as the elites. Leftist populists tend to villainize the corporate elites, particularly the bankers, and exclaim that those specific elites are a product of special interests, not popular sovereignty. Rightist populists believe that the people's economic sovereignty is expressed within the market, and the problem occurs when the elites erode consumer choice. Like leftist populists, rightist populists see the elites as the bureaucrats and government officials who intervene within the market and regulate companies and industries and provide social services for others. The special interests are then the people who benefit from such regulations and social services (Laycock, Visions).

These basic parameters define the vague boundaries of populism. When a specific context for populism, such as democracy, is identified, the picture of populism that we can paint becomes clearer and more useful. First, this broad profile of populism explains why the Tea Party and the Occupy Wall Street movements both qualify as populist 
movements, since they fulfill the following dimensions of a populist movement: a crisis at the genesis of the movements, the appeal, "the people" vs. "the elites," and the trajectory of the movements that shape the political debate and discourse. This lays the foundation for discussing the two movements as true populist movements.

With respect to the Tea Party, Switzer explains it as a response to a widespread feeling of "economic anxiety and political estrangement" among the American people. Therefore, we can identify the crisis at the genesis of the Tea Party movement as the economic collapse of 2008, which led to the Troubled Asset Relief Program (TARP) and the American Recovery and Reinvestment Act, or more commonly known as the bailout packages and stimulus, respectively (Foley, 8). The soon-to-be Tea Party folks were greatly angered by the growing size of government and the increasing involvement of the public sector with the private sector, particularly when, as taxpayers, they saw themselves having to foot the bill for the irresponsible actions of others. CNBC's Rick Santellli suggested that Chicago have its own Tea Party to protest this government intrusion into the private sector via bank and corporate bailouts. Of course, the idea of a Chicago Tea Party refers back to the Boston Tea Party, in which colonists protested a tea tax imposed on them by a parliament in which they believed they had inadequate representation. (Foley, 8-10; Miller, 4-6). This problemization between the people and the government in regards to the Tea Party is something I will expand on later in this chapter.

The central appeal or demand of the Tea Party can be boiled down to three central themes, which are limited government, U.S. sovereignty, and constitutional originalism. First, the call for limited government is a response to the Tea Partiers feeling that the government has overstepped its bounds by injecting itself into the free market and being 
fiscally irresponsible with federal funds (Foley, 19; Miller, 9). This resulted in a call for measures such as a balanced budget amendment to rein in congressional spending. This sentiment was only reinforced when Obamacare was passed in 2009. The people who support the Tea Party movement believe that Obamacare infringes on individual rights because it puts government in a position to determine the perimeters of an individual's health care (Foley, 10; Miller, 6).

Secondly, Tea Party supporters are solid defenders of U.S. sovereignty, which they believe is under attack in the international community. The primary reason why the Tea Party movement is concerned with U.S. sovereignty is because the movement's supporters believe that some international institutions, such as the United Nations, and some international treaties are unconstitutional and infringe on the rights of the people as well as negatively alter the role of government (Foley, 19). Tea Party supporters see domestic politics through the lens of John Locke, in which citizens' negative rights should be protected from the power of the government; however, they see international politics through a Hobbesian lens where states act, and should act, in their own self interest on behalf of their citizens (Foley, 19, 78-80). Therefore, the U.S, should act in the interests of American citizens first and not sign away its sovereignty with treaties that do not protect those interests.

The Tea Party movement's third theme is constitutional originalism. There are two schools of thought when it comes to interpreting the U.S. constitution: constitutional originalism and living constitutionalism. The former interprets the constitution through the lens of what the authors of the constitution most likely meant, also known as original intent. The latter interprets the constitution through the lens of how the constitution 
should apply in light of current values. The Tea Party movement embraces the former because they believe originalism preserves the authority of the constitution, which keeps the government in check. Today the Tea Party believes there has been an erosion of the separation of powers, and government officials and regulators have acquired too much power (Foley, 19, 169, 210). The erosion of the principles of how government should work and how it should protect the rights of its citizens is an example of the aforementioned problem of the pragmatic part of democracy being taken over by the elites. The Tea Party is the redemptive response to that problem.

The next distinctive feature of populism is that the actors involved with the movement and the problem can always be expressed as "the people" vs. "the elites," respectively. As is the problem with populism in general, the Tea Party people are more defined by who they are not; therefore, identifying "the elite" first should provide insight into "the people." The Tea Party sees the elites as the group of politicians, political insiders, and the corporate executives and bankers who pushed for the stimulus bills and the private sector bailouts. This is an example of the problem of equality that Laycock described above. Scholars have done work in identifying the political bent and demographic profile of "the people" that constitute the Tea Party. Politically, the Tea Party has been described as including suburban libertarians, rural conservatives, fiscally conservative housewives, and even pundits. Most of the Tea Party supporters selfidentify as conservatives, and less than $10 \%$ self-identify as Democrats. Therefore, it would be appropriate to classify the Tea Party movement as a politically right-oriented movement (Mead). Additionally, claims by politicians that the Tea Party is "astroturf," meaning it is funded by right wing elites instead of being a true grassroots movement, 
have been discredited by the emergence of numerous independent Tea Party groups spontaneously forming around the nation (Miller, 9).

Demographically the Tea Party is more representative of the American population than has been portrayed in the media. A USA Today and Gallup poll discovered that Tea Party supporters tend to be a little more male, white, and economically well off than the general population, and Tea Party supporters reflect the portion of minority ethnicities of the general population across the board with the exception of African Americans. There have been accusations that the Tea Party movement is racist, but the only actual data on that matter only suggests that some radical Tea Party supporters have expressed racist sentiment and the movement as whole, including its fringe, is only slightly more racist than the general population (Foley, 16-17).

The divide between the people and the elites in relation to the Tea Party movement can be best summed up with two Rasmussen Reports cited by Courser. Courser frames the conflict between the two actors involved in the Tea Party movement as the political class vs. the mainstream and concludes that the former is significantly out of touch with the latter. A significant majority of the political class believe that the federal government has the consent of the governed, the nation is heading in the right direction, all tax increases do not require voter approval, and the financial bailouts are a good idea. However, a significantly small minority of the mainstream feels the same way. Additionally, only $2 \%$ of the political class identify themselves as a member of the Tea Party, and only $16 \%$ of them see the Tea Party in a favorable light (Courser). This disparity between the elite and the people is very telling of the disconnect upon which the Tea Party was formed. 
The trajectory of the Tea Party has been an interesting one, to say the least. First, Rick Santelli's call for a Chicago Tea Party sparked the idea for a nation-wide, twentyfirst century tea party. Then Glenn Beck's 9-12 Project launched a Tea Party rally in Washington, D.C. on September 12, 2009, serving as a call to return to America's founding values and limited government of America. A libertarian group, Freedom Works, also became involved in the rally by getting the necessary permits for the protest. After the Tea Party demonstration in September, Nancy Pelosi called the Tea Party an astroturf movement, meaning she believed that it was funded by wealthy donors and was not a movement of the people. Since then, some scholars have rejected this portrayal of the Tea Party because of the grassroots response to the movement, which has spawned numerous local groups across the nation (Miller, 9-10; Mead). One scholar believes that the Tea Party should be considered a semi-populist movement because of its financial backing from the Republican Party (Formisano, 8-15). The problem with this "semiastroturf" stance is that is does not recognize that there are countless local Tea Party groups that are not funded by any party machine or corporation. These local Tea Party groups comprise the heart of this populist movement and are genuinely grassroots groups.

To date, the Tea Party has influenced national politics in significant ways. The first and most noticeable influence was the 2010 mid-term elections. Fifteen senatorial candidates in 2010 were self-identified Tea Party candidates who were elected received support from local Tea Party groups, and some of them even won their election. (Miller, 21). The Tea Party has also been a key element that pushed the Republican Party and some Independents to call for a repeal of Obamacare. As I write this thesis, the Supreme 
Court decision on Obamacare is pending, which is also evidence of the backlash fueled by the Tea Party.

Thirdly, the balanced budget amendment that the Tea Party called for in response to increasing national deficits and an explosion of the national debt has already been considered in the House of Representatives (Foley, 21). Although it did not pass, it is still significant that a constitutional amendment proposed by the Tea Party movement made it to the floor of the House (Washington Post). Another way in which the Tea Party has influenced Congress directly is that the demand for federal fiscal responsibility ignited a national debate on raising the debt limit ceiling, which had been unprecedented. Until 2011, it was considered a routine any other time the debt ceiling was raised. The pressure the Tea Party put on Washington combined with the Tea Party supporters on the Hill resulted in an uphill battle when President Obama would rather raise the debt ceiling than cut expenditures.

Interestingly enough, some scholars have already made some determinations on whether or not the Tea Party is a populist movement. For several reasons I content that the Tea Party movement should be classified as a populist movement. First of all, the Tea Party movement was a reaction to a crisis, which is characteristic of populist movements. Secondly, the Tea Party presents a set of appeals, or demands, that were not being met by the current institutions until people began to protest. This is a result of the people believing that their will and interests are not being represented by their representatives in government. Thirdly, the Tea Party is a movement of a group of people that represent part of the mainstream against the political class, or elites, which also includes the executives and bankers who made deals with the political elites. In this regard, Tea Party 
movement is a response to the problems of representativeness and equality that Laycock has identified.

The Tea Party is also responsible for shaping the national political debate and political discourse along the three populist criteria identified by Taggart. First, the Tea Party has brought a level of simplicity to the political discourse in terms of the language utilized by the discourse. Catch phrases like "taxed enough already" (the acronym for "tea" in Tea Party) and the focus on the constitutionality of the individual mandate have brought the political debate into the realm of the "common people." Secondly, the Tea Party has highlighted the idea of sovereignty of the people in politics with the scrutiny of Obamacare. The backlash against an unpopular law has led to that law going before the Supreme Court, a phenomenon that only happens to a handful of laws (Daly). Finally, the Tea Party dichotomizes debates, such as the debt ceiling debate. We could either raise the debt ceiling and saddle the next generation with even more debt, or we could not raise the debt ceiling and live within our means (Phillips).

Finally, the absorption of the Tea Party has already begun to take place with some congressional Tea Party candidates winning their races in the 2010 mid-term elections. After the 2010 mid-term elections, the Tea Party became partially institutionalized with the creation of the Tea Party Caucus headed by its chair, Congresswoman Michele Bachmann. This follows the general trajectory of populist movements: when their demands are heard parts of the political class begin to address their demands, institutionalize parts of the movement, and then the movement fades. When the movement fades still remains to be seen, and the upcoming 2012 election should be telling of how much influence the Tea Party has as a populist movement. Some Tea Party 
supporters, such as Senator Marco Rubio of Florida, resent the institutionalization of the Tea Party on the Hill (the Tea Party Caucus) because he believes that the very institutionalization runs counter to the essence of the Tea Party (Foley, 213).

Based on these reasons, I find it appropriate to classify the Tea Party movement as a populist movement; however, scholars such as Courser disagree with me. Courser uses Canovan's work to create a framework to define democratic populism, which brought him to three traits that fit those explained above and as follows: the belief that the people's consent is the source of a government's legitimacy, the belief that the people's representation within the democracy is not what it should be, and the result of mobilization to restore the representation of the people within the democracy. Courser concludes that the Tea Party is not truly a populist movement because it has not mobilized voters because it is too unorganized to do so. Even with the emergence and victories of the "Tea Party candidates," only around 29\% of Tea Party groups in America volunteered on campaigns during the 2010 mid-term elections, and of those groups who volunteered, they only worked on individual campaigns and not for a political party (Courser).

I would respond to Courser by saying that this difference in mobilization between Canovan's definition of democratic populism and the Tea Party can be explained with Taggart's notion of new populism. Since the 1970s, populist movements in Western Europe and America have become increasingly hostile towards political parties, more so than previous populist movements. Therefore, it would make sense that populist movements would be reluctant to align themselves with a political party or even form a political party. The fact that the Tea Party has inspired people to run for office, use the 
Tea Party demands as their platforms, and run as a candidate of a major political party seems significant, affirming that the Tea Party fits better as a new populist movements.

The Occupy Wall Street protest should also be considered a populist movement. Describing the Occupy Wall Street protest is challenging because it appears to be even more dispersed and less organized than the Tea Party. However, I believe enough information is available for me to describe it as a populist movement in the same manner as the Tea Party. To begin with, the crisis that sparked the Occupy Wall Street movement is twofold. First, a general anger arose over entitlement and public employee wage and benefit cuts in the U.S., such as the case in Wisconsin and the protests against Governor Scott Brown's budget cuts (Nichols, 4, 84). Secondly, the austerity cuts in Europe that led to riots in the street and the Arab Spring, which was the series of revolutions in the Middle East against the ruling class, created an international crisis with which the Occupy Wall Street wished to express solidarity. Like the Tea Party the Occupy Wall Street movement focused on the economic crisis of 2008. However, unlike its contemporary movement from the right, Occupy Wall Street blamed greedy corporations, bankers, politicians and the rich "1\%" of America (Nichols, 84; Van Gelder, 1-3).

In the late summer of 2011, an anti-capitalist Canadian magazine Adbusters called for Americans to express solidarity with the European riots and Arab Spring by protesting and "occupying" Wall Street on September 17, 2011. By the end of that day, hundreds of occupiers set up camp in Zucotti Park in New York's financial district to protest against Wall Street, big banks, big corporations, and the politicians who support them (Van Gelder, 1). A General Assembly of sorts was formed around the time of the birth of the occupation. This assembly met at seven o'clock every night to discuss what the demands 
of the movement should be and plan the basic logistical support for the movement (Van Gelder, 20).

As the Occupy Wall Street movement grew to a national movement, its set of demands solidified. The central theme of the movement was that the $99 \%$ of society is oppressed by the wealthiest $1 \%$ of society. The latter hold a majority of the wealth and make greedy decisions that lead to disasters at the expense of the former, like the economic collapse of 2008. This produces the demand that the political and economic elite respect "the right of we the people to create a world that works for the 99\%" (Van Gelder, 2, 45). Unlike the Tea Party's demands, those put forth by the Occupy Wall Street movement represent a rather long list. It is problematic because the extreme dispersal and "big tent" nature of the movement makes it difficult to identify a clear list or summary of demands, though the oppression of the $99 \%$ provides the basic essence of the Occupy Wall Street movement's concern. However, before the occupation began protesters voted on which one demand they should adopt. The top demands are as follows: revoke corporate personhood, raise taxes on the top $2 \%$, abolish capitalism, tax Wall Street, public health care, presidential commission to separate money from politics, and end corporate welfare (Cook).

The people that comprise the Occupy Wall Street movement are, like any populist movement, hard to label. This movement, however, makes it particularly difficult because it invites people to just join the occupation and bring whatever complaints and demands they have to the group to be part of the discourse. The elite, or the group of people against which the people of the Occupy Wall Street movement fight are the politicians, bankers, CEOs, Wall Street employees, and, in general, wealthy Americans. 
The Occupy protesters believe these elite are responsible for the economic collapse of 2008 and its subsequent consequences, such as house foreclosures and high unemployment rates (Van Gelder, 2, 6; Nichols, 84). This is an example of Laycock's problem of inequality expressed by leftist populist movements. Like other leftist movements, the Occupy Wall Street supporters believe that the source of economic inequality is the corporate elite and those who assist them.

The trajectory of the Occupy Wall Street movement began with a Canadian activist magazine, Adbusters, which called upon Americans to occupy Wall Street, but there was not much of a message to the movement at first. In fact, in the beginning the movement's critics scoffed at the fact that future protesters were voting for their central message on Facebook before they launched their protest. Eventually Occupy Wall Street settled on the message that the people are the $99 \%$ and are being oppressed by the wealthiest $1 \%$. This simple message has had a profound influence on the political discourse in American politics. Just looking at the presidential race thus far, Romney, the wealthy business executive, is being criticized for being wealthy and out of touch with the people (a.k.a., the "99\%"), and President Obama has tried to express solidarity with "the people" with the "99\%." This message is simple, emphasizing the need for the people to legitimize the acts of the ruling class because it highlights that the actions of the elite are harming the people instead of acting in the best interest of the people, and it expresses a clear cut, dichotomy between the 99\% and 1\% (Schoen, Miller Z.).

Like the Tea Party, Occupy Wall Street also meets the basic criteria of a populist movement. In particular, both of them are the product of the problemization of representativeness and a problem of equality, which is a definite sign of democratic 
populism. In the two following chapters, I will clarify the populist aspects of both of these movements. In the second chapter, I will fit the Tea Party and Occupy Wall Street movements within the seven types that form the spectrum of populism. Finally, in the third chapter, I will discuss the history of American populism and then focus on the American populist aspects of both of these movements. These chapters will solidify the appropriateness of categorizing both the Tea Party and the Occupy Wall Street movements as populist movements. 


\section{Chapter 2: Varieties of Populism}

One way to generate a more accurate profile of populism is to use historical examples as guides to subdivide populism into two categories, and these can be broken down further into a total of seven types. As mentioned before, when scholars widen their definitions of populism, they forego important elements of some or most of the populist movements they study. On the other hand, if the definition of populism is too narrow, that definition will exclude some movements that should be considered populist movements. For the sake of both clarity and inclusiveness, Canovan developed seven types of populism, which have been validated by other populist scholars. In this chapter, I will identify the seven types of populism, provide historical examples of each of them, and then situate the Tea Party and Occupy Wall Street movements within the populism framework.

The first category is agrarian populism, which encompasses the farmers' radicalism populism type, the peasant movement type, and the intellectual agrarian socialism type. This category of populism is more rural-based and is concerned with the socio-economic factors and problems that affect rural communities. The second category is political populism, and the types it includes are populist dictatorship, populist democracy, reactionary populism, and politicians' populism. In contrast to the first category of populism, political populism is less concerned about socio-economic problems and more concerned about political problems. These movements push for measures such as direct democracy because it increases citizen participation in politics and demand that the government and political elites enact the will of the people. It is important to note that one populist movement can be a combination of more than one type of populism. In fact, 
Canovan describes various populist movements as examples of two or three populist types (Canovan, Populism, 8-13).

Figure 2: Varieties of Populism

\begin{tabular}{|c|c|c|}
\hline Type & Definition & Example \\
\hline Farmers' Radicalism* & $\begin{array}{l}\text { Farmers organize and create bottom-up populist } \\
\text { movement against the gov't, monopolies, etc }\end{array}$ & Prussian Farmers \\
\hline Peasant Movement* & $\begin{array}{l}\text { Bottom-up movement that speaks for the people } \\
\text { (peasants); pro-rural, anti-town }\end{array}$ & $\begin{array}{l}\text { Green Uprising-Eastern } \\
\text { Europe }\end{array}$ \\
\hline $\begin{array}{l}\text { Intellectual Agrarian } \\
\text { Socialism* }\end{array}$ & $\begin{array}{l}\text { Subset of elites infuse the people with populist } \\
\text { uprising to create a socialist society }\end{array}$ & Narodniki in Russia \\
\hline Populist Dictatorship** & $\begin{array}{l}\text { Charismatic leader builds dictatorship by opposing } \\
\text { the elite and appealing to the people }\end{array}$ & Peron in Argentina \\
\hline Populist Democracy** & $\begin{array}{l}\text { Restoring government by the people; involves the } \\
\text { implementation of direct democracy }\end{array}$ & Switzerland \\
\hline Reactionary Populism** & $\begin{array}{l}\text { Conservative reaction against liberally educated } \\
\text { elites; anti-progressive }\end{array}$ & $\begin{array}{l}\text { Religious Revival, } \\
\text { 1970s }\end{array}$ \\
\hline Politician's Populism** & $\begin{array}{l}\text { Style of politics that appeals to the people, creates } \\
\text { catch-all parties, and "big tent" political platforms }\end{array}$ & Reagan, 1980s \\
\hline
\end{tabular}

*-Agrarian, **-Political

The first category I will discuss is agrarian populism, which contains three types of populism that have a spectral relationship to each other. On one end of the spectrum there is intellectual agrarian socialism, on the other end is farmers' radicalism, and peasant movements in the middle. The best way to understand agrarian populism is to interpret it through a heartland vs. ruling class framework. As explained in the first chapter, the heartland represents the imaginary territory that represents the values and lives of the everyday people, which are worth defending. In the following examples, the peasants and 
farmers represent the heartland and are at the center of the populist movements. The ruling class, or elite class, is the power structure that is either unwilling or unable to meet the demands of the people, like in all populist movements. The important difference in intellectual agrarian socialist populism is that a subset of the ruling class, or elites, that infuse the heartland with populist demands in order to overthrow the rest of the ruling class (Taggart, 95).

The first type, intellectual agrarian socialism, is a type of populism that is characterized by a subset of elites firing up the masses to revolt against the other elite and the government. This is different from other types of populism in which the populist movement originates on the grass roots level instead of being transplanted there by elites who believe they are thinking of the best interest of the masses. From the 1890s until 1917, Russia has a rich history of intellectual agrarian socialist populism until the populist uprising became assimilated into the socialist Bolshevik revolution. In the 1890s, there was a small group of radical intellectuals, whom the Russian intelligentsia called the narodnik or "populist." Due to their western education, they were alienated who were alienated by the regime and other elites, who imagined an idealized socialist society. From their position in society, removed from the masses, these intellectuals determined that the masses needed land and liberty, although the land and liberty the radical intellectuals wanted to give were not completely aligned with what the masses wanted for themselves. As the socialist part of the populist label suggests, the radicals romanticized a more communal situation for the masses, whereas the masses envisioned a world in which idle landowners did not own land, but rather the actual producers and workers owned the land. 
The agrarian aspect of this type of populism refers to the focus of the narodniki on the social aspects of change instead of the political aspect of change. Their idealized vision of the masses did not inherently elevate the masses to a political level, but rather the narodniki's vision entailed the enfranchised masses living on communal land and engaging within a socialist economic system. The struggle with Russian populism is that it never gained much traction with the masses. The lead radical intellectuals who tried to project their movement onto the masses and elicit a revolution of sorts were forced to engage in political maneuvering just to avoid or reverse being exiled (Canovan, Populism, 60-88).

After the assassination of Czar Alexander II and his family and the interim government began to fall, narodniki had a golden opportunity as challengers who wanted to rule Russia. The most successful of these challengers were the Bolsheviks, who organized the October Revolution in 1914 and won the Russian Revolution in 1917. Even though the radical intellectual socialist populists did not win the revolution, they did achieve a victory in another sense. After the Bolsheviks came to power, they incorporated populist aspects into their political program. I would go further than Canovan here and suggest that part of the Bolshevik's success was due to the fact that at the beginning of the 1914 revolt and later fed into the Russia Revolution in 1917. They had already woven aspects of radical intellectual socialist populism into their agenda. An example of this is the inclusion of property rights in Lenin's April Theses. This was later manifest in the form of communal farms, which is what the narodniki envisioned as well. The reason the Bolsheviks were successful in the Russian Revolution is because they not only had the 
actual military power but they also had the support of the masses due to their populist appeal (Lee, 27-28).

At the other end of the spectrum of agrarian populism is farmers' radicalism, which is characterized by a grassroots populist uprising that originates with the farmers, or producers, that demand particular action be taken by the plutocrats, corporations, governmental institutions, elites, etc. The classic American example of farmers' radical populism is the populist uprising that began in the 1890s and grew into the People's Party, a national political party. Because I will describe this movement in great detail in the next chapter of this paper, I will turn to a non-American example to explain this type of populism. In the 1890s, during the birth of the U.S. populist movement, a parallel movement was taking place in Germany. Prussian Junkers, or German farmers, grew grain that they sold on international markets. During the last part of the nineteenth century, the Junkers experienced a drop in the selling prices for their grain and a rise in the debts they owed. In reaction to this, the Junkers organized themselves and formed the German Farmer's League. The German Farmer's League was a radical organization with the purpose of defending the rural interests of the Junkers that turned to government intervention as a tool it could use to satisfy its demands (Canovan, Populism, 103-104).

Unlike the radical intellectual socialist populism, farmers' radical populism is a movement that begins as a grassroots movement and moves up, sometimes to the point where the movement is overtaken by the elites themselves, as we will see with America's People's Party in the 1890s. Radical intellectual socialist populism is the opposite in that its trajectory is meant to go from the top with the radical subset of elites and trickle down to the masses so that the masses mobilize against the system the radical elites wish to 
change. Between these two extremes of agrarian populism is a third type of agrarian populism, which is peasant populism. Like the radical intellectual socialist populism, peasant populism is very pro-rural and anti-town and is less likely to be for government intervention. It has a similar goal of wishing to speak from the point of view of the peasantry or masses. Like the farmers' radical populism, peasant populism stresses the virtue of the producer, originates on the grassroots level, and is anti-plutocratic in nature (Canovan, Populism, 132).

The most salient examples of peasant populism occurred in Eastern Europe after World War I, which is approximately the same time of the Russia Revolution and the incorporation of Russian populism into Bolshevikism. Peasant populism in Eastern Europe led the Green Uprising within Poland, Czechoslovakia, Yugoslavia, Bulgaria, and Romania simultaneously. The peasant populations of these nations ranged from $63 \%$ to $80 \%$ of the general population, giving the peasantry a substantial amount of potential political power. The setting for the Green Uprising was set as these five nations formed democratic constitutions, which led to a unique opportunity for the peasantry to access democratic rights. The two options available to the peasants were either modern capitalism or socialism. They rejected this dichotomous decision and opted for a democratic society in which family property, rural values, and societal cooperation were cornerstones. Although peasant populism was short-lived in these countries, it did impact the national political scene for a time.

More than simple political conditions sparked the peasant populist movements in Eastern Europe in the first part of the twentieth century. Like other peasant populations, the peasants in Eastern Europe faced famine, land shortages, and extreme land plot 
subdivisions, which left them with an insufficient amount of land to work to produce enough for their landowners and themselves. In Romania in the early 1900s, peasants suffered under the competition of international markets that drove up rents to the extent that workers were being overworked in keeping their landowners' crops and undernourished as their own crops fell to pieces in their own fields. Poor food supply in terms of both quantity and quality boosted the rate of disease among peasants. These factors generated enough exasperation that the Romania peasantry revolted in 1907. It was not until at least ten thousand Romanians died that this movement was quelled.

Bulgaria followed a similar trajectory as Romania after it become independent from the Turks in 1879 . The Turks had developed a society with an army and bureaucracy that required extensive money to be maintained. This meant that the upper class, located in the urban regions of Bulgaria, were privy to high-end jobs that were furnished by the working peasantry. On top of that, the peasants were required to pay a tax in the form of agricultural produce. Once the Bulgarians had been liberated from the Turks, this tax was removed. However, in 1899, during one of the worst famines the peasants had faced, the Bulgarian government decided to reinstitute the tax. This became the key element in the origins of a radical peasant uprising, that resulted in the Bulgarian Agrarian Union and paved the way for land reforms and new, pro-peasant policies (Canovan, Populism, 112119).

Thus far, I have discussed agrarian populism, but even the three types of populism under the agrarian populism are only half of the types of populism. The second category, political populism, contains four types of populism, the first of which is populist dictatorship. At first, a populist dictatorship sounds like a contradiction of terms. A 
populist dictatorship includes a charismatic leader who creates a dictatorial regime based not on focusing on winning over the elite, but rather on winning over "the people." I will be looking at Peron in Argentina as a case study for a populist dictatorship and discuss the rationale for why "the people" would support a populist dictator (Canovan, Populism, 137). First, however, I would like to discuss the regional aspects of Latin American populist dictatorships to provide a theoretical framework for my discussion of Peron. As I mentioned in chapter one, the study of populism began in comparative politics; therefore, I find it appropriate to summarize some of the regional characteristics of populism here.

There are three characteristics of Latin American populist dictatorships that contribute to the autocrats being able to manipulate and ultimately mobilize the people and distinguish this type of populism from other types. First, there are some similarities to the rural radicalism populism type; however, the important difference between the two is that "the people" in the Latin American populist dictatorship are ex-peasants and urban workers, not peasants as in rural radical populism. Second, in the Latin American cases of populist dictatorships, there are catch-all parties with the autocrat being the charismatic head of the party. Finally, the third characteristic is that, like in rural radicalism, the people are mobilized from above instead of at the grassroots level (Canovan, Populism, 138). A primary case of populist dictatorships is the case of Juan Domingo Peron of Argentina. Within the study of Latin American populist politics, there are two opinions in regards to the Peron case. The first opinion held by scholars is that Peron is a classic case of Latin American populist dictatorships because of its trademark charismatic leader and the fact that the urban masses were mobilized. On the other hand, 
the second opinion in regard to the Peron case is that it is an atypical case because Argentinian labor played such a vital role Peron's regime (Canovan, Populism, 141).

Near the end of World War II in 1943, Peron and his fellow army officers overthrew the conservative Argentinian government. The reason Peron was the officer to consolidate power and become the autocrat was because he was the only officer to care to look to the people for support once the army gained power. Peron focused on courting the labor and trade unions, providing the workers with physical benefits as a reward for their loyalty. Of course, as is usual with autocrats, Peron ruled with oppressive tactics, but what made his rule a populist rule is that he fashioned himself as a ruler of the people. When he addressed the people, he did so with his sleeves rolled up to identify himself with the urban workers. He habitually spoke out against the landowning oligarchy and the supporters of the U.S. imperialists. In this way, Peron focused on the enfranchisement of the lower class of people and brought them into the political sphere for the first time (Canovan, Populism, 143-145).

Before Peron's rise to power, others in Argentina tried to gain power but failed because they could not gain the support of the labor movement. The labor movement was so predominant in Argentinian politics from around 1915 until after World War II because the industrialization of the economy led to the ability of workers to unionize on a large scale and become a political force. In 1916, Hipolito Yrigoyen tried to consolidate his power by building alliances with the union factions; however, the workers chose to support the other political parties (the anarchists, socialists, and union syndicates) instead of supporting Yrigoyen. In 1930, the military coup also failed to create an effective alliance with the unions and workers. By the military coup of 1943, some things had 
changed that helped facilitate Peron's consolidation of power. However, the most important difference between Peron and others who tried to rise to power is Peron's use of populist methods to his advantage, which gives us a unique look at the application of populism (Di Tella, 131-134).

Post World War II, four parts of Argentinian society had to be balanced by anyone who came to power. First, there was a new class of entrepreneurs that had emerged during the war who feared a government that did not enact protectionist policies because their businesses would face ruin without such measures. With the growing dominance of trade unions and more politically predominant workers, a new government would have to take their demands of social welfare and state supported industrialization seriously, as well. Then there are the army's interests and the right-wing intellectual interests to balance within a new regime. The characteristically populist tactics Peron used were based on the general populist principal of meeting the demands of "the people." I would argue that Peron met the demands of two sets of "the people" in order to gain their support for his regime. The first group of "the people" are the workers and trade unions, who demanded that the government provide social welfare and state supported industrialization. The second group of "the people" were the new entrepreneurs, who demanded that the government institute protectionist policies so their businesses would continue to thrive (Di Tella, 133-138). By meeting these demands and fashioning himself as a charismatic man of the people, Peron appeased the different political powers enough to consolidate power for himself, much like the Bolsheviks during the Russian Revolution. 
Even in populist dictatorships, where the autocrats pander towards the interest of the people, the state is still under the rule of a dictator. Scholars have identified two reasons why people would subject themselves to populist dictatorships. The first is that the interest of the people is in opposition to that of the elites, like with Peronism. A populist autocrat who echoes the concerns and desires of the people and positions himself against the elite on behalf of the people serves the interest of the people more than the landowning elites who show no interest in responding to the people's needs as long as the people can be controlled. It is a matter of choosing the lesser of two evils. Even if all of the people's interests and desires are not fulfilled by the autocrat, it is more beneficial for the people to support the autocrat because the alternative is to support the other political power, the elites, which would result in the people having virtually none of their interests and desires fulfilled. The relationship between the autocrat and the people then becomes a patron-client relationship (Canovan, Populism, 160-161).

The first reason for the people supporting a populist dictatorship, as explained above, provides a rational explanation for why the people would support a populist autocrat. The second reason seems less rational, but it is based on essentially cornering the people so their only option is to support the dictator. "Mass" theorists have identified an intriguing phenomenon that has increased in frequency in modern society. Groups of people evolve into "masses" when those people have been removed from their homes and communities, which results in social and political disenfranchisement. This disenfranchisement leads to a yearning for community, authority, and a locus on which they can place their pain and hardships, which makes the "masses" particularly easy to manipulate. A populist dictator takes advantage of this kind of situation by creating a community for these people, 
becoming their authority, and giving them an enemy on which to focus their pain, which would be the landowning oligarchy, or the elites (Canovan, Populism, 163-164).

Post-colonial African states provide good examples of this second rationale for the people supporting dictators. The interesting thing about many of the cases in Africa is that the emerging ruling elite in post-colonial Africa came from the lower and middle echelons of the social and political structures. This naturally positioned the elites close to the people because they were once part of the people themselves. The elites used this intimate rapport with the people for their own political gain, coupled with charisma and the practice of prebendalism (the practice of state offices and positions of power being exploited to benefit select portions of the population to garner support for those in power). This led to Big Man rulers, or populist dictators (Worsley, 140-150). A Big Man ruler is one who does not separate his public self from his private self, has a personalization of his leadership, is a charismatic leader, and engages in neopatrimonialism (personal rule that involves the use of public resources for personal gain, which is typically inevitable when merchant and industrial structure is weak and underdeveloped) (Hyden, chapters 3,5). The charismatic connection between the ruler with a personalized ruling style and a people is characteristic of populist dictators. I would argue that the practice of neopatrimonialism within a context where isolated workers have no choice but to adhere to a Big Man ruler in hopes of getting what they need fits the description of the second rationale for people supporting populist dictators (Hyden, Worsley). The difference between the post-colonial African case and the Peron case is the latter recognizes the people as a political force whose demands need to be balanced with the demands of other political forces. 
The second type of political populism is populist democracy, which was discussed at length in the previous chapter. To review, populist democracy is when the people have a set of demands that are not being met by the current governmental institutions that claim to represent them. Because these kinds of movements center around a problem of representativeness and anger about the lack of citizen participation in the policy-making process, they often result in the emergence of direct democracy, such as referendums and initiatives (Canovan, Populism, 137). Direct democracy takes some of the power that was once entrusted to the representatives of the people and returns it to the people in the form of direct political participation in the formation of public policies.

America offers several examples of populist democracy movements, but since next chapter describes many of them in detail, I will how describe the democratic system in Switzerland reflects the aspects of populist democracies. The Swiss case provides an example of what direct democracy looks like in the local and federal levels of government and serves as the ideal outcome of citizen participation, which is a central demand of democratic populist movements. The Swiss case of democracy populism is unique because from the federal level through the constitution and the local level, the Swiss government is significantly influenced by direct democracy, specifically initiatives and referendum. Members of the First Assembly, the national parliament in Switzerland, are elected directly by the people to serve as representatives that are charged with executing the will of the people. The highest level of government is the Federal Council, which is comprised on seven ministers chosen by the Assembly. One of those seven ministers is selected as the Federal President, who acts as the chair of the Federal 
Council. Both of the Federal Assembly and the Federal Council are subject to the will of the people through direct democracy.

Unlike other democracies, initiatives and referendum are actually built into the federal and cantonal constitutions. The government institutions do not have the ability to present referendum. Rather, the power to place referendum on ballots for the public to consider lies within the people, who get to control the content, timing, and presentation of the referendum they present. Additionally, whenever a constitutional amendment is presented, the constitution requires that it be presented to the people as a referendum for the approval of the people. From 1848 to 1978,300 national referendum were put up for a vote, of which 212 have been required by the constitution. Also, within that same time frame, out of the 125 initiatives that have called for a change to the federal constitution, only 7 have passed.

This strong presence of direct democracy within Swiss politics does not end at the federal level. Many of the local Swiss cantons rely on the use of direct democracy to conduct their routine affairs. The canton, Appenzell Inner-Rhoden, is a prime example of this. On the last Sunday of every April, the 14,000 people of Appenzell Inner-Rhoden come to a large general meeting for the purpose of airing their grievances, settling their financial and legal disputes, receive reports, and select new administrators to serve the canton until their next annual meeting (Canovan, Populism, 198-201). This local and federal system centered on direct democracy within Switzerland is the idealized result that democratic populist movements desire. It is part of the solution for the problemization of representativeness and fulfills the desire for increased citizen participation in the political process. 
The third type of political populism is reactionary populism. Reactionary populism is "the mobilization of popular conservatism, ignorance, and prejudice in opposition to the progressive and enlightened views of the more educated and liberal elite" (Canovan, Populism, 137). Since the most salient examples of reactionary populism come from American politics, I will leave the explanation of the case studies of reactionary populism to the next chapter. I would, however, like to mention that the religious revival of the 1970s is an example of reactionary populism that I will cover in detail later.

Finally, the fourth type of political populism is politicians' populism, which is a type of populism that is utilized by the elites or candidates running for office to garner a broader base of support. The way they do this is to make general appeals to the people that transcend the otherwise salient political boundaries of ideology, class, and party lines within that context. This can happen with people not only in the mainstream political parties, but it also occurs in the formation of emerging political parties or "catch-all People's Parties" (Canovan, Populism, 137).

Politicians using populist rhetoric use one of five strategies to convey a populist message. The first strategy is for politicians to position themselves as anti-political and speak out against the political status quo, unifying the people against the political elite. The second strategy is to portray one's party as the only choice for the party that represents the people. Thirdly, some politicians use "catch-all pragmatism," which is a strategy that involves making non-ideological stances to increase the support of the politician. In other words, politicians create "big tent" parties that include as many people as possible. Fourthly, politicians can also create a group of "common people" that transcend the typical class structures by juxtaposing the elites against them. Finally, 
politicians can also take advantage of the vague nature of "the people" by using populist rhetoric to gain support. Cases of politicians' populism are quite predominant in American politics. Nixon and Carter implemented populist tactics to gain support and win the American presidency. Interestingly enough, Nixon repackaged George Wallace's reactionary populist tactics as politician's populist tactics, which led to Nixon's victory (Canovan, 248). These three cases are detailed, in the next chapter on American Populism.

Now that I have explained the seven types of populism and provided case studies for each, I will situate both the Tea Party and Occupy Wall Street movements within this classification system of populism. First, however, I would like to reiterate that one case of populism can fall under more than one type of populism, and it is not unusual for a populist movement to exhibit aspects of different types of populism. So one movement can be classified under more than one type of populism.

I will begin with the classification of the Tea Party movement. The agrarian category of populism can help us classify the Tea Party movement. First, like farmers' radicalism and peasants' populism, the Tea Party is a grassroots movement, which began because people felt like the government was not listening to their demands of fiscal responsibility and adherence to constitutional freedoms. Additionally, the Tea Party also idealizes the traditional moral values of the past, and similar to the Green Uprising in Eastern Europe (an example of peasants' populism), values a democracy, and an economic system that is not socialistic or modern capitalistic (in the Tea Party context, the problem with modern capitalism is state intervention). Like farmers' radicalism, the Tea Party also used the electoral system to achieve their goals by electing people sympathetic to their cause. 
However, unlike these two types, the Tea Party is not solely a rural-based movement. In fact, the movement appears not to adhere to the traditional rural/urban socio-economic and political cleavages. In regard to intellectual agrarian socialism, the one similarity it shares with the Tea Party is that a few people considered part of the elite spurred the genesis of the Tea Party. Besides that, no other similarities between the Tea Party and intellectual agrarian socialism beyond the basic characteristics of populism are evident.

Turning to the political populism category, we can rule out populist dictatorship because there is no autocratic system in which the Tea Party movement operates. Furthermore, there is no sole leader of the Tea Party trying to establish a dictatorial regime with the popular support of the people. Populist democracy is an appropriate type of populism to relate to the Tea Party movement because it came to be and exists within a democracy. The underlying reason the Tea Party came into being is because enough people felt that they were not being represented the way they believed they should be. Mobilizing as a movement is the expression of that lack of representation and lack of their demands being met by the current political institutions. Also, the Tea Party movement's involvement in the electoral system is characteristic of other populist democracy movements, such as the People's Party in the 1890s (this movement can also be classified as farmers' radicalism).

In fact, many politicians used the emergence and anger of the Tea Party movement to try to get elected or re-elected to public office in the 2010 mid-term elections, and some of them succeeded. This is a classic case of politician's populism, as these candidates used the populist rhetoric and anger of the Tea Party to appeal to a broad base of voters to get elected. This co-opting of a populist movement for political gain by candidates and 
politicians is nothing new. The same thing happened with the People's Party of the 1890s in the United States. Once the grassroots populist uprising became a national party, it split on a North/ South divide, tried to insert itself into the presidential race, and then the party fell apart as it combated the Democratic Party machine. I would argue that the actual Tea Party movement itself and the way in which candidates and politicians are using its rhetoric and existence for their political gain are two separate beasts. The Tea Party movement in and of itself is not a politician's populist movement, but the Tea Party movement did lay the foundation for a politician's populism Tea Party movement.

The final type of populism is reactionary populism. The tricky part about addressing this particular type of populism is that populism, by definition, is reactionary. It reacts against the political elite, the economic elite, and the social and political institutions that are not adequately satisfying the demands of "the people," and it can be best understood as a conservative reaction against progressivism. The Tea Party movement is a reaction against government intervention in the free market system through stimulus packages and bailouts, the perception that the government is overtaxing the people, and the belief that the government is eroding the negative rights of the people as outlined in the U.S. Constitution (in other words, the government is threatening the traditional moral values of the people). Reactionary populism is more than just a reaction against the elite, but it is a conservative reaction against liberally educated elites and progressivism. Due to the strong connection the Tea Party movement has draw between itself and the American Revolution (and traditional founding values) and its rejection of progressive governmental measures, such as an extension of positive rights (or entitlements) and free 
market intervention, I believe classifying the Tea Party as a reactionary populist movement is accurate.

Next, I will compare the seven types of populism against the Occupy Wall Street movement in order to provide some possible classifications for it. In regard to agrarian populism, Occupy Wall Street is similar to the Tea Party in that it is not a rural-based movement like the three agrarian populism types. In fact, the Occupy Wall Street movement has occurred in city centers and college campuses and appears to have no ties to rural communities. Like the Tea Party, Occupy Wall Street movement was also started by a few people within the media before it became a grassroots movement, which is characteristic of intellectual socialist populist movements. Another characteristic the Occupy Wall Street movement shares with intellectual socialist populism is that both want a more egalitarian, or socialized, economy.

The Occupy Wall Street movement does not fall into the type of populist dictatorship for the same reasons the Tea Party does not, but it can be classified as a populist democracy movement just like the Tea Party. Unlike the Tea Party, however, Occupy Wall Street would not be considered a reactionary populist movement because the Occupy Wall Street movement is not reacting against the liberally educated elite and progressive measures taken by the government. In fact, the Occupy Wall Street movement wants the opposite; they want the government to take more progressive measures by intervening in the free markets more because they believe that big businesses and corporations are part of the economic, political, and social problems the U.S. faces today. Occupy Wall Street supporters want the government to create a more socialized, or egalitarian, economic system by taxing the rich and giving more 
entitlements to the poor and middle class people. Nonetheless, Occupy Wall Street is a reactionary movement; it happens to be a progressive reactionary movement, whereas the Tea Party is a conservative reactionary movement.

Finally, in relation to politician's populism, the Occupy Wall Street movement follows the Tea Party movement's pattern in that politicians are adopting the rhetoric of the movement for their own personal gain. Even President Obama has begun to use populist rhetoric and phrases like "the 99\%" (the slogan of the Occupy Wall Street movement) in his addresses to voters. The difference between Occupy Wall Street and the Tea Party is that the latter actually made electoral politics part of their focus and the former has not. Because the former had not emerged until after the 2010 mid-term elections, it remains to be seen how much Occupy Wall Street will influence the next election cycle in 2012. Interestingly enough, Occupy Wall Street supporters have criticized the movement for not following the Tea Party's example and involving itself in electoral politics. 


\section{Chapter 3: American Populism}

American history has a rich populist narrative in which previous populist movements have shaped their successors. The best way to understand the contemporary American populist movements, the Tea Party and Occupy Wall Street, is to understand the general history of populism in America. Much of the same rhetoric, strategy, and sentiments expressed since before the American Revolution have been utilized over and over again during many populist movements, including the Tea Party and Occupy Wall Street. In this chapter, I will discuss the general characteristics of American populism and describe previous American populist movements that are foundational to the Tea Party and Occupy Wall Street movements. During my discussion of the Occupy Wall Street movement, I will also include a comparison of the Tea Party and Occupy Wall Street movements. An important aspect of this chapter to note is that I will describe instances of politician's populism, which will be useful in explaining how politicians and would-be politicians have and may respond to both the Tea Party and Occupy Wall Street movements.

According to Michael Kazin, American populism is based on both "vision and protest," which can occur concurrently or separately. The first basis of American populism, the vision, is a religious aspect, which can be best described as a Great Awakening, or spiritual revival in which the people embrace a fight against sin as their Christian duty. I will discuss the rise of the religious right in American politics in the 1970s later in this chapter, which is a prime example of this kind of populism. The second basis of American populism, as Kazin explains, is "the belief that ordinary people could think and act rationally, more rationally, in fact, than their ancestral overlords 
(Kazin, 10-11)." Many of the historical cases fit this type of American populism, such as Jeffersonianism and the People's Party in the 1890s. These two versions of populism will give us a better understanding of American populism as we move forward. First, I will describe the Tea Party's lineage within American populism (Figure 3), and then that of the Occupy Wall Street movement (Figure 4).

Figure 3: Tea Party's Historical Lineage

\begin{tabular}{|l|l|}
\hline \multicolumn{1}{|c|}{ Historical Movement } & \multicolumn{1}{c|}{ Type(s) of Populism } \\
\hline Sons of Liberty/ Sam Adams & democratic populism, politician's populism \\
\hline Jeffersonianism & democratic populism, politician's populism \\
\hline Wallace/ Nixon & politician's populism, reactionary (Wallace) \\
\hline Religious Movement of the 1970s & democratic populism, reactionary populism \\
\hline Ronald Reagan & politician's populism, reactionary populism \\
\hline
\end{tabular}

Figure 4: Occupy Wall Street Historical Lineage

\begin{tabular}{|l|l|}
\hline \multicolumn{1}{|c|}{ Historical Movement } & \multicolumn{1}{c|}{ Type(s) of Populism } \\
\hline Jacksonianism & politician's populism, democratic populism \\
\hline Farmers' Alliance/ People's Party & democratic populism, radical farmers' populism \\
\hline Student Protests, 1960s/1970s & democratic populism \\
\hline Jimmy Carter & politician's populism \\
\hline WTO Seattle Protests, 1999 & democratic populism \\
\hline
\end{tabular}

Of course, the first American populist movement resulted in the American Revolution. As Alan Wares points out, before 1776 some American colonists developed 
hostility towards the central British government that was only perpetuated by the War for Independence. The founding of the United States as a democratic republic not only expressed the ideas of government of, by, and for the people, which is foundational to democratic populism, but also formed a framework for future American populist movements. Jeffersonianism, which exposes the importance of personal freedom and the limitation of government as much as possible within society, has been an important set of principles for populist movements since the Revolutionary era. The American Revolution also cemented a general distrust in government that American populist movements have continued (Meny and Surel, 108). Coupled with Jacksonianism, which promoted the "common man" as a reaction against the educated elite, Jeffersonianism was foundational for future American populist movements as they repeated the principle of "equal rights to all, and special privileges to none (Hackney, 84, 99).” Then, in the 1860s, Abraham Lincoln filled a new role within iconic American populism.

In fact, Michael Kazin views Jefferson, Jackson, and Lincoln as the three populist heroes of American populism, and he has an interesting way of juxtaposing these three different men together. First, he views them within their historical contexts, identifying Jefferson as the hero of the Revolutionary era, Jackson as the hero of the Age of the Common Man, and Lincoln of the Civil War (Kazin, 17). More importantly, however, is how Kazin labels these heroes. He describes Jefferson as the philosopher and intellectual who generated the political maxims of American populism. Jackson, with his military background and forceful presence, is the hero who represents the war against the elites. Lincoln, with his humble beginnings, is the hero who represents the common man 
(Kazin, 24). I will explain more of these populist movements and the three populist heroes below.

The Revolutionary era did not begin with Jefferson, however. The Sons of Liberty began in 1765 when groups of colonists in different colonies organized themselves to protest the results of the Stamp Act. In Albany, colonists protested "the appointment of a local deputy to the colony's stamp collector." In North Carolina, “organization became necessary after customs officials in Cape Fear started seizing vessels with unstamped clearances." Similar citizen movements occurred shortly after these protests in Wilmington and Virginia. By the beginning of 1766, under the leadership of Sam Adams the Sons of Liberty officially formed and began issuing public announcements. Even though the Sons of Liberty were men from the middle and upper echelons of society, they wanted to represent the "body of the people," which included white men and property owners (they believed white men were automatically property owners because they owed freedom). They made significant efforts to reach out to the masses; even though they had to keep their activities secret because of the treasonous nature of their venture, the Sons of Liberty were actually more interested in communicating their ideas and strategies to the people than hiding them from the British. Of course, the Sons of Liberty were responsible for the Boston Tea Party, which helped catalyze the revolution (Maier, 84-90; 277).

What made the Sons of Liberty a populist movement are their demands, their opposition to the elite, and the way they invoked the masses. First, their demand focused on the unjust measures handed down to them by the British Parliament and the Crown. Beginning with the Stamp Act and later the Tea Act, the Sons of Liberty believed that 
their government was not representing them or acting in their best interest, which is the problem of representativeness discussed in chapter one. They also felt that the current governmental institutions were not responding to their outrage against these acts, which resulted in protests. Secondly, even though these men were from the middle and upper classes of colonial society, they positioned themselves against the local governmental officials and the government, painting King George as a tyrant taking away the liberties of the colonists. Finally, despite the fact that these people were not a part of the masses, their message and tactics were aimed at the people with a purpose of including the people (at least, the way they defined "the people").

While the Sons of Liberty and Sam Adams are known for setting the stage for the American Revolution, Thomas Jefferson is known for being one of the men who shaped the philosophical foundation of the American republic. Jefferson identified the monarchs, such as King George III, and the aristocracy as the elite against whom the people should rise because this elite unjustly consume what the people produce (Kazon, 15). This message of the elite consumers taking from the producers (the people) without doing any producing themselves is a message that resonates with other American populist movements, such as the People's Party of the 1890s. Jefferson was the only intellectual of the Revolutionary era who thought of the problem as an elite vs. the people problem. He believed that government should protect the people from injury and, as he said government "shall not take from the mouth of labor the bread it has earned (Kazin, 18)." This kind of rhetoric becomes central to future movements.

Jefferson's rhetoric and political philosophy should be considered populist because of its demands, the crisis, the conflict between the actors, the trajectory of the movement 
that surrounded the formation and expression of these ideas, and how these ideas affected the political discourse of its time. First, the demands of Jeffersonianism can be boiled down to one theme: the people have a right to live under a government that both respects their natural rights and truly represents the people. This idea comes from the crisis that followed the Stamp Act and Tea Act, which imposed taxes on the British colonies in America. These acts started a crisis because many of the colonists believed that they did not have legitimate representation in the British parliament, which they expressed as a problem of "taxation without representation." This crisis also created the division between "the elite" and "the people." In this case, "the elite" were the British parliament and the British monarch, King George III, and the "the people" comprised of the American colonists who were not being sufficiently represented by the body that governed them.

The American Revolution and Jefferson case is a classic example of the problem of representativeness that has been discussed throughout this thesis. The problemization of representation between the political class (elites) and those they represent (the people) is the mark of democratic populism; therefore, the Sons of Liberty and Jeffersonianism should also be classified as democratic populism not only because of the problem of representativeness, but also because of the trajectory of the combination of the two. Even though the Sons of Liberty started in the upper and middle echelons of colonial society, their cause received enough support from the rest of the people to lead to the Revolutionary War. This led to a government formed for, by, and of "we the people," which is a predominant feature of democratic populism. 
The Sons of Liberty and Jeffersonianism are foundational to the Tea Parry movement in several ways. First of all, the Tea Party is named after the Boston Tea Party to express solidarity with the Sons of Liberty's Boston Tea Party in 1773. Both tea parties are focused on the problemization of representativeness. The Boston Tea Party was an expression of anger about being forced to pay taxes when they did not feel adequately represented in the British Parliament that had created and imposed the taxes. Likewise, today's Tea Party is an expression of citizens believing they are overtaxed and the government is not representing their demands sufficiently. Next, Jefferson was a fierce proponent of limited government and natural rights, which are also a central tenets of the current Tea Party. Finally, the Tea Party has aligned itself with the Boston Tea Party and the founding fathers to portray its call to return America to its traditional values, such as limited government and constitutional originalism, which relates to the Tea Party's reactionary populist characteristics.

During the 1960s and 1970s, another expression of populism was embodied in the lay politician George Wallace. Wallace, an Alabama man, fashioned himself as the "average Joe" and redneck, with "Stand up for America" as his slogan, preaching to his fellow Southerners that the South was a victim of prejudice. He positioned himself as a "guardian of the South," claiming he fought to keep the northern states from infiltrating the South and involving themselves in southern affairs. In this way, he is considered a reactionary populist politician because of his vehement responses to progressivism. As governor of Alabama in 1962, his slogan was "Stand up for Alabama," which he did. Among other things, Wallace fought the federal government's policy of forced 
desegregation (Meny, Surel, 145-151). Then Wallace turned his attention to the presidency.

In 1968, Wallace challenged Johnson as a third party candidate with the American Independent Party, which Wallace himself had created. He claimed that Johnson was not in touch with the common man as much as Johnson claimd to be. As Joseph Lawndes stated, "Wallace aimed to go national to save the local (Meny, Surel, 152-169)," which is what drove Wallace's presidential campaign. Wallace managed to get 10 million votes $(13.5 \%)$ as a third party presidential candidate because of his popularity with blue collar workers and his racist, tough-on-crime, traditionally moral platforms. Wallace was a product of the reactionary nature of populism that mounted a fight against the elites (Canovan, 227, 229). However, as is characteristic of American populism, the establishment co-opts the populist talking points to help them garner the people's support. After Wallace's defeat, Nixon co-opted Wallace's rhetoric, moderated it, and used it to propel himself to victory in 1968 (Meny, Surel, 163).

After Nixon's Watergate scandal, a profound mistrust of "mainstream politicians" and outrage over the removal of religion from education set the stage for a rendezvous of the religious right and political right in the 1970s. For Protestants the issues of school prayer and the teaching of evolution in the classroom were of greatest importance, and for Catholics the issues of abortion and communism were the most disconcerting. What is interesting about this grassroots populist movement is that women were the central actors of protest instead of men, as in previous movements. In fact, women took to the streets reciting the rosary and protesting the extraction of religious values from the public education system. The protesters saw the politicians and mass media as the elites who 
were removing religion from the public square, such as schools, which led them to find alternate means of communication such as direct mail and locally owned newspapers and radio shows (Kazon, 256-260). Recall that Kazin identified religious spiritual awakenings as one brand of American populism. Here, that religious call aimed at the common man, the common Christian, to fight $\sin$. It grew to become a political call for the common man re-insert himself into national politics. Like many previous movements, this populist uprising paved the way for a populist leader to step forward, take up the cause first expressed by the grassroots protesters, make it a national message, and use it as a central part of his/ her political platform. This movement is of particular interest because it is a reaction against a president who utilized populist rhetoric to get elected and then led to another populist president.

After the religious and political right fusion, Reagan emerged and finally merged the Catholic and Protestant brands of religious populism that had surfaced in the 1970s. Reagan's speeches were filled with past populist rhetoric, most specifically, claiming that the people want "an end to... a punitive tax policy that does take "from the mouth of labor the bread it has earned (Kazin, 263)." This rhetoric is the same populist messaging Jefferson used. His image was also likened to Jackson by his contemporaries because of his ability to articulate a strong message of a desire of freedom originating from grassroots America. His cowboy image also endeared him as a man of the common people, much like Lincoln. His message of people gaining freedom and empowerment by the government getting out of their lives (a response to the New Deal rhetoric) spoken plainly completed his politician's populist appeal (Kazin, 261-264). 
The group of elites Reagan positioned against the people included two kinds of elites. Like the religious right movement of the 1970s, Reagan attacked the establishment, more specifically, the "special interests." He portrayed them as liberal elitist insiders who were running the corrupt institutions. The other part of the elite, related to the first, were the minority groups. Reagan's rhetoric was not anti-minority in terms of promoting racist or sexist ideas, but rather Reagan and his supporters were against the privilege they believed minority groups received. They saw it as a matter of inequality when minority groups received entitlements or perks not available to the people at large (Kazin, 262). The points discussed above in regards to Reaganism and the movement that proceeded is quite helpful for understanding the Tea Party movement.

These two movements provide examples of a democratic populist movement that became hijacked and turned into politician's populism. When the religious base believed that their values and beliefs were being attacked, they were mobilized into demanding that their religious views have a place in the public square, specifically the pubic school system. Like other democratic populist movements, these movements had a conflict between the people and the elites, a crisis, a set of demands, and a belief that the people are not truly being represented as they should within the government. The religious revival of the 1970s should also be considered a reactionary populist movement. As explained in chapter two, reactionary populism mobilizes against the liberal, educated elite. Reagan, the politician, recognized the traction this movement received and decided to absorb their demands into part of his platform. Of course, Reagan expressed populist rhetoric on non-religious issues, but this hijacking of a democratic populist movement by a politician is part of a pattern in American populist movements. 
The religious movement in the 1970s and Reagan share similar characteristics to the Tea Party. First, like these previous movements, the Tea Party is a conservative reaction to the emergence of progressivism. The Tea Party is also distrustful of the mainstream political culture like the religious movement of the 1970s was. Additionally, like Reagan, the Tea Party is also angry over the producer being overtaxed. They both believed that the "special interests" are the ones benefitting from government policies while the people foot the bill. As noted before, the Tea Party is beginning to be used by politicians for their own gain, much like Reagan used populist rhetoric and the populist movement of the 1970s. These three movements look back to the past and romanticize traditional times and values, much like the rest of the populist movements included in the Tea Party's historical American populist lineage.

The lineage of the Occupy Wall Street movement began with Jacksonianism, the populist movement centered around President Andrew Jackson. President Jackson was a frontiersman who flaunted his lack of formal education and intellectual training, rejecting the over-reaching power of the political and intellectual elite. The persona he presented to the nation strongly resonated with the frontiersmen belief "that the judgment of the ordinary man was more reliable than that of the highly educated (Canovan, 233)." The message and tenor of the Jacksonian movement later became a theme for American populist movements to come. Additionally, as mentioned before, Jackson is credited with waging war against the elites. For Jackson, the elites were the "money power" of the aristocracy, who, with their stocks, bonds, and other instruments in the financial sector, created artificial reflections of human labor. Like Jefferson, Jackson also drew upon the 
producer/ consumer rhetoric to define the problem between the elite and the people (Kazon, 19-20).

Jacksonianism should be classified as both politician's populism and democratic populism. First, however, I would like to discuss what makes Jacksonianism populist in the first place. The crisis seems to be best explained in terms of a disconnect between the workforce and the wealthy class, which led to a divide between the laborer (the people) and the "money power" (the elites). A problem also existed with the educated, intellectual elite trying to make political decisions that the people did not support, which is the mark of democratic populism's problem of representativeness. Jackson's call to return to relying on the wisdom of the common folk in particular is a mark of politician's populism because the call is coming from a politician wishing to gain popular support. Because Jacksonianism is significantly focused on one politician using populist rhetoric for popular support and it stirred the people to demand a restoration to their representativeness in government, both politician's populism and democratic populism would be appropriate types for Jacksonianism.

Like Jacksonianism, the Occupy Wall Street movement has positioned itself against the "money power," much as its name reflects. This stems from a disconnect between the working class and the wealthy class, also an element of Jacksonian populism. Both Jackson and the Occupy Wall Street movement had a severe animosity towards bankers and the financial sector because they believe that they exploit the producer/ consumer relationship. The Tea Party is angry about money issues, but their anger is focused on an increase in the public sector and the expansion of government. The Occupy Wall Street movement calls for more government intervention into the private sector, which creates a 
sharp contrast between these two contemporary American populist movements in terms of the matter of "money power."

One of the most well-known instances of American populism that scholars identify is the People's Party of 1892 and the events that culminated in the emergence of that political party. After the Civil War, farmers in the South and in the West experienced an agricultural boom that was swiftly followed by a decade-long drought that destroyed the farmers. This resulted in a mass exodus of many of the farmers, and the few who did stay endured severe hardship. They ended up in debt to the merchants that sold the farmers the goods they need, and because the crops were so bad for so long, that debt accumulated from harvest season to harvest season. This put the merchants in control of what the farmers could and could not have. When a farmer would hand the merchant a list of the goods he wanted to purchase usually the merchant would not give him everything on the list, and the items the merchant would give the farmer would not be given in the quantity requested. The farmers did not take this kind of treatment well, especially because the farmers highly valued self-reliance and independence (Canovan, Populism, Ch 1; Hackney).

This frustration culminated in farmers creating a Farmers' Alliance to combat the injustice the farmers perceived they experienced. In 1880, farmers from the West and South met in Texas, which could be considered the beginning of that populist movement. Lecturers spoke about how the farmers were the laborers in the country, but others had made the laws. Another message they delivered was that the producer is suffering when the non-producer is not. Many of the leading orators of the Farmer's Alliance used quotations and rhetoric from both Jefferson and Jackson in regard to the problematic 
relationship between the producer and consumer. This movement was not just confined to Texas. Across the West and South, groups of farmers were getting together and having revivalist-like meetings. The larger goal of all these groups was to affect change, which they did. The Jute Bag Boycott of 1889 was a substantial victory for the Alliance, as they banded together to boycott high bagging prices for cotton (Canovan, Populism, Ch 1).

Although the 1889 boycott proved effective for the Alliance, their success did not continue for long. The incorporation of the Alliance into politics was problematic because it splintered the group along ideological and racial lines. The rise of populism in Kansas followed a different narrative, though. In March 1890, the County Alliance presidents decided to remove their support for the mainstream parties after the Republican Party had failed to effectively answer their appeals and frustrations. This resulted in farmers withdrawing from the Republican Party and backing the emerging People's Party, whose campaign in the summer of 1890 rejuvenated the Kansas farmers and "common folk." Populist speakers, many of whom were women, spoke at rallies claiming that Wall Street was the problem and the source of the hardships of the common people. In Florida, however, instead of forming a new party, which was considered taboo, the Alliance infiltrated the Democratic Party to enter the political field (Canovan, Populism, Ch 1).

The populist farmers were not only concerned with agricultural issues but also with currency issues (Goodwyn, The Populist Movement, 265). At this point in American politics, a debate emerged as to whether or not the U.S. currency should be backed with gold, silver, gold and silver, or simply not backed by a precious metal at all. This issue did divide the Alliance when it moved into politics directly. However, the populists' free 
silver platform did resonate enough with Democrats that in 1896, the Democrats nominated William Jennings Bryan on his free silver stance. Although this was a populist platform, this was only one of many, so the Populist convention tried to split its allegiance by affirming Bryan as the presidential nominee, but then nominating Tom Watson as the vice presidential nominee, much to Bryan's disapproval. The Republicans campaigned hard, threatening to shut down businesses and such to secure the presidency. Bryan's defeat effectively ended the Populist Party (Canovan, Populism, Ch 1).

The Occupy Wall Street protest, like the Farmers' Alliance, is a populist movement against Wall Street and a financial system that does not serve the interests of the “common man." Occupy Wall Street claims that Wall Street and the wealthy investors are the ones that created the economic crisis of 2008, which has resulted in problems like unemployment and the housing crisis. Like the Farmers' Alliance, Occupy Wall Street sees these problems being created by the wealthy $1 \%$ elite of America who are not the people suffering for the havoc they have caused. Instead, the consequences have been placed on the shoulders of "the people," "the 99\%." Interestingly enough, the Occupy Wall Street movement has already been linked to William Jennings Bryan. Brookhiser asserts that the former can learn an important lession from the latter: a concrete agenda and political activity should be part of the movement. Additionally, they should also worry about their appearance and the public perception, which was part of Bryan's defeat. Bryan's harsh rhetoric was demonizing and made him unpopular with too many Americans.

On the other hand, the Tea Party believes the crisis and problematic solutions implemented after the crisis are a result of the elite rejecting a framework of limited 
government. Both the Tea Party and Occupy Wall Street movements have not formed political parties like the People's Party, but politicians are using the populist rhetoric of each of these movements. I will say, however, that a shift away from American populist movements using the electoral system would be characteristic of new populism. However, as explained in chapter one, the Tea Party has used the Republican party to elect some Tea Party "candidates" in order to enact a national Tea Party agenda in Washington, D.C., much like the People's Party elected candidates for local and federal offices.

After the People's Party disintegrated and the Democratic Party absorbed some of the political messages of the populist movements (Goodwyn, Democratic Promise, 506-507), the nature of American populism evolved. American populism still is decentralized in nature, but it has a tendency to reach the national level of politics and become a feature and tool of American politics (Meny, Surel 101). This makes American populism distinct from other populist movements. As Wares explains, "in contrast to other countries, populism in the United States has not stood apart from mainstream political values and traditions, nor have its solutions for institutional restructuring been distinctive (Meny, Surel, 111)." After the end of the People's Party, this feature of American populism became more predominate, particularly in the Tea Party and Occupy Wall Street movements. As explained in chapter one, both the Tea Party and Occupy Wall Street are decentralized and are grassroots movements that grew to the national level. Additionally, both of these movements have been purposely removed from "mainstream politics" even though some politicians have tried to co-opt them and bring them into the mainstream. 
The series of student protests in the 1960s and 1970s is another example of an American populist movement. The protests were directed against the political elite because the students believed the political elite did not truly executing the will of the people, particularly on matters of foreign policy. These protests also attacked the elitist nomination machine, and in the $60 \mathrm{~s}$ and $70 \mathrm{~s}$, the nomination process for political office shifted from the party elites' control towards more of the people's control (Meny, Surel, 115). However, this movement was far less organized than the previous populist movement that produced the People's Party. The students were significantly decentralized and did not have a unifying, identifying ideology that could describe the movement. Canovan says this is because, like other populist movements, the student protest movement was a reactive movement that mobilized students against the political elite. Therefore, she suggests that the best way to analyze this movement and others that are similar is not in terms of ideology but in terms of contributions to the public discourse (Meny, Surel, 31). It seems that the student movement created more of a platform for students to express any anger they generally held towards elites or the government instead of being incorporated into an existing political platform, like a political party would do. This is characteristic of both the Tea Party and Occupy Wall Street movements.

The students began what was referred to simply as the Movement because they believed that the workers, consumers, and minorities in America (the people) fell victim to the "power elite" and the "power structure" that were trying to take away the people's ability to organize themselves. They wanted to return to the era of the New Deal, when which the government gave the people more entitlements and economic support. The 
demands of the Movement included the establishment of the welfare state, a greater proliferation of democratic labor unions, a rapid end to both poverty and racial discrimination (Kazin, 196). The protesters and supporters of the Movement believed they were not being represented properly within the government and wanted direct democracy so they could shape policy without having to go through a system that they saw as victimizing them. A call for direct democracy is an indicator of democratic populism because the people see it as the best solution to the problem of representativeness. I would also say that their lack of use of political parties to influence the political environment is characteristic of the new populism that arose in the 1970s. Interestingly, the impact the student protests had on the Vietnam War political discourse has been identified as largely negative because the public looked down on the movement and, subsequently, their demand to end the war (Gustainis).

The Occupy Wall Street movement has many similar characteristics of the student protests of the 1960s and 1970s. Both are decentralized protests that want the government to take a more active role in providing benefits to Americans, such as extending unemployment. Additionally, it is difficult to pinpoint the demands of these movements due to their "big tent," diffuse, non-hierarchical nature. Both have protested the elites and structure they believe is trying to harm the "common man," much like Jackson and the oppression of the "money power." In the 1960s and 1970s, the fear was that the elites were trying to hinder the people's ability to organize and express their opinions. Today, the fear is that the $1 \%$ will continue to manipulate the economy for their benefit at the expense of the $99 \%$. Both believe the government should help balance the inequalities within the political and economic spheres. In contrast, the Tea Party believes the problem 
is that the government thinks its job is to balance these inequalities; on the contrary, the Tea Party believes the government should afford everyone equal rights and get out of the private sector as much as possible. The Tea Party is the diffuse populist movement on the other end of the spectrum.

Recall that during the time of the student protests, American politics was also influenced by the religious revival and populist presidential candidates. However, Wallace and Nixon weren't the only presidential candidates in the 1960s and 1970s portraying themselves in a populist light by utilizing politician's populism. Jimmy Carter was a self-proclaimed populist who drew upon his family's agricultural background to try to connect more with the "common man" and win more votes. He drew upon Jacksonian rhetoric and the Farmers' Populist agrarian roots in an effort to widen his political base. As Canovan explains, it is not uncommon for politicians to claim to speak for the people, not just limited segments of the population, and create "big tent" platforms to increase their chances of winning elections. As Canovan states "one of the main functions of appeals to the people, indeed, is to cancel existing political divisions and to propose a realignment (Canovan, 260-262)." Of course, a candidate would propose a political realignment that would increase their own base while shrinking the base of their opponent. I want to revisit the idea of politician's populism in relation to the Tea Party and Occupy Wall Street movements in the conclusion, where I will discuss the current 2012 Elections.

In 1999, an intriguing development happened within American populism as a American populist movement went global. The World Trade Organization (WTO) planned a conference of 135 nations to increase free trade globally by deregulation in 
Seattle, Washington from November 30 to December 3, 1999. Two groups of Americans, the environmentalists and labor unions, groups that do not always work in concert, spearheaded the protest against the Seattle WTO conference. Their demands were that free trade not simply be adopted as a policy, but rather workers' rights and environmental protections also be at the forefront of the WTO's agenda. The AFL-CIO along with other big unions and some environmental groups planned a rally outside the place where the conference was held that shut down the WTO conference and led to its cancelation. The talks fell apart in 1999 and continued to be unsuccessful as the Doha Rounds into the twenty-first century (French, History Link).

The Seattle protest of 1999 should be considered a democratic populist movement because of the demands listed above that came from the crisis the protesters saw with the exploitation of workers and lack of environmental standards in developing nations. The bigger problem, however, was the fact that developed nations were willing to ignore these issues and enter into free trade agreements. The protesters represented the workers, environmentalists, and unions (the people) and saw the leaders of the nations and international capitalist economic system that perpetrated the inequality of wealth within and among nations as being the oppressive elites (French). Because this was a protest and not a call for the implementation of direct democracy, it is a bit harder to identify the problemization of representation within the government structure. However, I would argue that the protesters were rallying against the lack of representation of "the people" within the capitalist economy.

The Seattle WTO protest shares many of the characteristics of the student protests of the 1960s and 1970s, but the difference to note is the global dimension of the former. 
This is interesting to note since the Occupy Wall Street movement is linked to other contemporary movements around the world. The Seattle protest follows the same pattern of positioning itself against the capitalist system and the economic elite, or "money power," like we have seen with other movements that are a part of Occupy Wall Street's lineage. This move towards a more international movement seems to be the new piece that the Seattle protest adds. The problem with a globalized populist movement is that a populist movement exists inside a state, not between states or people of different states. For a populist movement to be transcribed from one state to a next, there must be a basis for the movement in the latter, which is what we saw with Occupy Wall Street. The existing frustration of the "99\%" was what was built upon by Adbuster's call for an occupation of Wall Street. Because the Tea Party is significantly steeped in American traditions, it is highly unlikely that it will globalize. Oddly enough, Glenn Beck is now calling for a global Tea Party movement, which would be an intriguing development in both the Tea Party and American populism (Martel). 


\section{Conclusion:}

Although populism is a cumbersome topic of study, we can identify five central dimensions of essentially every populist movement. First, populism always involves two groups of actors, which are best described as "the people" and "the elites." The people are the heart of the movement as they are the ones against whom wrongs have been done, and the people are seen as the common, ordinary men and women of society. On the other hand, the elite are seen as the aggressors who have wronged the people, and the elite are typically politicians, corporate executives, special interests, or any other group of individuals that the people see as being too powerful. Secondly, in populist movements the people have a set of demands that the elite and their elitist institutions or government structures have either failed to meet, cannot meet, or both. These demands become the themes of the movement and are the reasons for mobilization. Thirdly, the uprising of the people with a set of demands is not spontaneous; populist movements are reactionary movements that arise during a time of crisis. An economic collapse, political scandal, and famine are all examples that have been the crises that have catalyzed populist movements. Fourthly, depending on their origins, populist movements follow two trajectories. They can either be grassroots movements that begin at local levels and grow to national movements along a bottom-up trajectory, or they can begin with a leader or as a national set of demands and trickle down to the local, grassroots level, which would be called a top-down trajectory. The important thing is that populist movements have a grassroots element because of the central role "the people" play within populism. Finally, populist movements have three distinct effects on the public discourse, which are the following: introduce simplicity and plain language to the debate, emphasize the 
sovereignty of the people as key to legitimizing policy decisions, and create dichotomies of the issues. Based on these five general criteria, the Tea Party and Occupy Wall Street movements are populist movements. Furthermore, based on the analysis of democratic populism in chapter one, which includes the problem of representativeness, the problem of equality, and the conflict between the people and the elites within democracy, the Tea Party and Occupy Wall Street movements should also be considered democratic populist movements.

In chapter two, I explained the seven types of populism that provide specific features to different kinds of populism to clarify what populism looks like in different contexts. The seven types can be divided into two categories, which are agrarian populism and political populism. Agrarian populism includes farmers' radicalism, peasant movements, and intellectual agrarian socialism. Political populism includes populist dictatorships, populist democratic movements, reactionary populism, and politician's populism. After the review of the key elements of each of these types of populism, I have categorized the Tea Party as reactionary democratic populist movement that has led to politician's populism. I categorize the Occupy Wall Street movement as an anti-reactionary democratic populist movement that may evolve into politician's populism. Because the Tea Party is a conservative reaction to progressive policies with a call to return to traditional American values, it should be considered a reactionary populist movement. On the other hand, Occupy Wall Street is a progressive movement on the other end of the political spectrum, so, if anything, it should be considered a progressive reactionary movement. Both of these movements occur in a democracy and focus their message on the problems of representativeness and equality, which makes 
them populist democratic movements. Finally, we are seeing politicians use the rhetoric of both of these movements for political gain, which is characteristic of politician's populism.

The historical lineages of the Tea Party and Occupy Wall Street movements within American history have created different historical narratives for both of these movements. First, the influence of the Sons of Liberty with their Boston Tea Party, Jeffersoniansim, and the religious movement of the 1970s on the Tea Party is evident in the Tea Party's values of American traditions, limited government, and constitutional orginialism. The use of politician's populism by Jefferson, Wallace, Nixon, and Reagan is interesting because of how this coincided with the aforementioned populist movements, which helps explain the emergence of "Tea Party candidates" in the 2010 mid-term elections. However, a national political "Tea Party" has not been established, and Tea Party supporters have only worked on individual campaigns and have not aligned themselves with an existing political party. In this way the Tea Party is more diffuse on the national level than these previous movements, similar to the Occupy Wall Street movement in its narrative.

The democratic populist movements that help define the Occupy Wall Street movement are the Farmers' Alliance, which became the People's Party in the 1890s, the student protests of the 1960s and 1970s, and he WTO Seattle protest of 1999. These three progressive movements mobilized against the capitalistic monopolies and large corporations to which to the people became subjected. It is important to note that the Seattle protest was a protest about the global capitalist economy, as this global influence is also present in the Occupy Wall Street movement. Jacksonian rhetoric about the 
oppressive "money power" is reflected in the Occupy Wall Street movement's problem of the wealthiest $1 \%$ of the nation creating problems and the $99 \%$ bearing the consequences. Jimmy Carter is another example of a populist politician that ideologically aligns with the Occupy Wall Street movement. Like in the case of the Tea Party, politicians have identified with the movement. In fact, Congressman Earl Blumenauer (D-OR) released a statement expressing solidarity with the movement after he visited the Occupy Portland protest (Blumenauer; Redden). An "Occupy Voting Booths 2012" is the closest the Occupy Wall Street movement has come to being involved in electoral politics, though (Facebook). They have not endorsed candidates; instead, they simply urge people to make their voices heard via voting.

Because diffuse movements that are anti-political party and anti-government institutions do not last very long, I would not expect the Tea Party or Occupy Wall Street movements to have much staying power. By the 2016 presidential elections, I would expect both of these movements no longer to exist as populist movements. I would expect, however, that both of these movements follow a trajectory similar to that of the People's Party of the 1890s in which the two main political parties will continue to incorporate the populist rhetoric and policy ideas of either the Tea Party (Republican Party) or Occupy Wall Street (Democratic Party) into their own political agendas. This is something we are already witnessing. This incorporation will effectively end the populist movements because their ideas will become part of the institutional political order, which is the absolute opposite of populism. A new crisis could reignite one or both of these movements, but I believe that would only delay this predicted trajectory. 
I anticipate the effects on the 2012 Elections will be generally subtle. Both presidential candidates, Barack Obama and Mitt Romney, have already been using populist rhetoric characteristic of the Occupy Wall Street and Tea Party movements, respectively, which suggests a significant possibility for these movements to be hijacked and turned into politicians populist movements. Because both the Tea Party supporters and Occupy Wall Street supporters are watching the political process more closely since the advent of these movements, I would expect to see a greater voter turn out than the previous presidential elections. Although there may be some demonstrations by groups identifying with the Tea Party or Occupy Wall Street movements and some of the supporters may volunteer for campaigns, I do not think the Tea Party or Occupy Wall Street movements will have any presence as a third party or organized interest group. For now, it looks like the Occupy Wall Street movement is interested in grassroots voter mobilization without a solid agenda beyond what people choose for themselves. The Tea Party's local offshoots seem to focusing more on local campaigns and local politics instead of the entire political process during this election cycle. Come November 2012, we will see the actual effects these movements have on the electoral process.

Beyond following up with the aforementioned predictions, I believe the next step in studying the Tea Party and Occupy Wall Street as populist movements should be with a comparative framework. The nature of the Occupy Wall Street movement strongly suggests that understanding political unrest and political uprisings around the world are germane to contemporary American populist movements. The Arab Spring, European riots, Iran's Green Revolution, and the internal conflicts in both Thailand and Hungary would be some of the twenty-first century uprisings that I believe should be part of such a 
comparative study. Recall that the Prussian farmer uprising and American farmer uprising were contemporary movements, and that they shared many similar features. With the advent of social media and an increased ability for people around the world to connect with one another, I would expect contemporary movements not only to have significant similarities but also to influence one another. 


\section{Bibliography}

Arditi, B. "Populism As a Spectre of Democracy: a Response to Canovan." Peace Research Abstracts. 42.1 (2005). Print.

Barr, R.R. "Populists, Outsiders and Anti-Establishment Politics." Party Politics. 15.1 (2009): 29-48. Print.

Blumenauer, Earl. "Blumenauer on Occupy Wall Street: 'Why Shouldn't the 99\% be Outraged?" Wednesday, 12 October 2011 17:38.

http://blumenauer.house.gov/index.php?option=com_content\&view=articl e\&id=1932:blumenauer-on-occupy-wall-street-qwhy-shouldnt-the-99-beoutragedq\&catid=62:2011-press-releases. Press Release.

Brookhiser, Richard. "What Occupy Wall Street Can Learn from William Jennings Bryan."American History, April 2012, 22-23. Print.

Canovan, Margaret. "Populism for political theorists?" Journal of Political Ideologies, October 2004, 9(3), 241-252. Print.

— Populism. London: Junction Books, 1981. Print.

— (1982) "Two Strategies for the Study of Populism." Political Studies, 30(4), pp. 544-552. Print.

- (1984) "People, politicians and populism." Government and Opposition, 19, pp. 312-327. Print.

— "Trust the People! Populism and the Two Faces of Democracy." Political Studies. 47.1 (1999): 2. Print.

Cook, Jim. "What is the One Demand of Wall Street Occupation? Facebook Poll Narrows Possibilities." Irregular Times, September 18, 2011. http://irregulartimes.com/index.php/archives/2011/09/18/what-is-the-onedemand-of-wall-street-occupation-facebook-poll-points-to-possibilities/ Online.

Courser, Zachary. "The 'Tea Party' as a Conservative Social Movement." Society, 49.1 (2012): 43-53. Print.

Daly, John. "The Supreme Court Vindicates the Tea Party.” March 31, 2012. http://www.bernardgoldberg.com/the-supreme-court-vinicates-the-teaparty/ Online.

Di Tella, Torcuato S. Latin American Politics: A Theoretical Framework. Austin: University of Texas Press, 1990. Print. 
- History of Political Parties in Twentieth-Century Latin America. New Brunswick: Transaction Publisher, 2004. Print.

Facebook. "Occupy Voting Booths" homepage http://www.facebook.com/OccupyVotingBooths. Online

Foley, Elizabeth Price. The Tea Party. New York: Cambridge University Press, 2012. Print.

Formisano, Ronald P. The Tea Party. Baltimore: The Johns Hopkins University Press, 2012. Print.

French, John D. and Kristin Wintersteen. "Crafting an International Legal Regime for Worker Rights: Assessing the Literature since the 1999 Seattle WTO Protests." International Labor and Working-Class History: No. 75, Spring 2009, pp. 145-168. Print.

Goodwyn, Lawrence. Democratic Promise: The Populist Movement in America. New York: Oxford University Press, 1976. Print.

—. The Populist Movement: A Short History of the Agrarian Revolt in America. New York: Oxford University Press, 1978. Print.

Hackney, Sheldon. Populism: the Critical Issues. Boston: Little, Brown, 1971. Print.

Holmes, William F. American Populism. Lexington, Mass: D.C. Heath and Co, 1994. Print.

Hyden, Goran. African Politics in Comparative Perspective. New York: Cambridge, 2006. Print.

Kazin, Michael. The Populist Persuasion: An American History. New York: Basic Books, 1995. Print.

Laycock, David and David P. Shugarman. "Review of Populism and Democratic Thought in the Canadian Prairies, 1910 to 1945." Canadian Journal of Political Science / Revue Canadienne De Science Politique. 24.1 (1991): 161-163. Print.

Laycock, David. "Visions of Popular Sovereignty: Mapping the Contested Terrain of Contemporary Western Populisms." Critical Review of International Social and Political Philosophy, Vol. 8, No. 2, 125-144, June 2005. Print. 
Laycock, David \& Marian Sawer. "Down with Elites and Up with Inequality: Market Populism in Australia and Canada." Commonwealth \& Comparative Politics. Vol. 47, No. 2, 133-150, April 2009. Print.

Lee, Stephen J. European Dictatorships 1918-1945. New York: Routledge, 1999. Print.

Lutz, Donald S. "Review of Populism." The Journal of Politics. 44.3 (1982): 893895. Print.

Maier, Pauline. From Resistance to Revolution: Colonial Radicals and the Development of American Opposition to Britain, 1765-1776. New York: Alfred A. Knopf, Inc., 1973. Print.

Martel, Frances. 'Beck Sums Up 'Global Tea Party' to O'Reilly: Individuals vs. the George Soros Machine.” Mediaite, February 21, 2012. http://www.mediaite.com/tv/beck-sums-up-global-tea-party-to-oreillyindividuals-vs-the-george-soros-machine/ Online.

Mayer, L C, E Kaymak, and J W. Justice. "Populism and the Triumph of the Politics of Identity: the Transformation of the Canadian Party System." Nationalism and Ethnic Politics. 6 (2000): 72-102. Print.

Miller, William J. and Jeremy D. Walling, ed. Tea Party Effects on 2010 U.S. Senate Elections: Stuck in the Middle to Lose. New York: Lexington Books, 2012. Print.

Miller, Zeke. "White House Draws Closer to Occupy Wall Street, Says Obama is Fighting for the Interests of the 99\%." Business Insider, October 16, 2011. http://articles.businessinsider.com/2011-10-

16/politics/30285591_1_house-spokesman-josh-earnest-president-barackobama-class-warrior Online.

Mény, Yves, and Yves Surel. Democracies and the Populist Challenge. New York: Palgrave, 2002. Print.

Nichols, Uprising. New York: Nation Books, 2012. Print.

Panizza, Francisco. Populism and the Mirror of Democracy. London: Verso, 2005. Print.

Redden, Jim. "Pioneer Courthouse Square rally gets Occupy Portland singing." The Portland Tribune, October 28, 2011. http://www.portlandtribune.com/news/story.php?story_id $=131984032958$ 178800. Online. 
Schoen, Douglas. “Occupy Wall Street Has Seized Control of This Year's Political Debate." The Daily Beast, April 28, 2012.

http://www.thedailybeast.com/articles/2012/04/28/occupy-wall-street-hasseized-control-of-this-year-s-political-debate.html. Online.

Schwartz, Michael. Radical Protest and Social Structure: The Southern Farmers' Alliance and Cotton Tenancy, 1880-1890. New York: Academic Press, 1976. Print.

Switzer, Tom. "The Rise and Rise of the Tea Party." Institute of Public Affairs Review: A Quarterly Review of Politics and Public Affairs, 62.4 (2010): 12-13. Print.

Taggart, P. Populism. Buckingham: Open Press University, 2000. Print.

Van Gelder, Sarah and Yes! Magazine, ed. This Changes Everything: Occupy Wall Street and the 99\% Movement. San Francisco: Berrett-Koehler Publishers, Inc., 2011. Print.

Worsley, Peter. The Third World: Second Edition. Chicago: The University of Chicago Press, 1967. Print.

“The U.S. Congress Votes Database." Washington Post. November 18, 2011. http://projects.washingtonpost.com/congress/112/house/1/votes/858/ Online. 